\title{
UK oil and gas fields: an overview
}

\section{G. GOFFEY ${ }^{1 *}$, J. GLUYAS ${ }^{2} \&$ N. SCHOFIELD ${ }^{3}$}

${ }^{1}$ Soliton Resources Limited, Twickenham, London, UK

${ }^{2}$ Durham Energy Institute, Durham University, Durham DH1 3LE, UK

${ }^{3}$ Geology and Geophysics, University of Aberdeen, Aberdeen AB24 3UE, UK

(D) GG, 0000-0002-8588-9632

*Correspondence: g_goffey@solitonresources.co.uk

This volume is the fourth in a widely spaced series of milestone Geological Society Memoirs on UK oil and gas fields. These Memoirs record the extraordinary journey of science, engineering, technological development, inspiration, dedication, occasional serendipity and sheer bloody-minded persistence which has led to the development of some 458 named oil and gas fields (OGA 2019) on the UK Continental Shelf (UKCS). As a side note, the origins of the names of many of these fields have been analysed by Young (2009). As an illustration of the scale of that more than 50-year offshore history, Figure 1 records by decade the 2767 exploration and 1879 appraisal wells drilled from the first well spud in late 1964 to the end of 2019.
As described on page ix, this Memoir is dedicated to the memory of John Brooks CBE who sadly died shortly before the Memoir went to press. In his very longstanding role with responsibility for exploration and licensing at the Department of Energy/Department of Trade and Industry, John was instrumental in encouraging exploration activity across the UKCS and onshore. Very many of the fields in this Memoir were found on John's watch. He was keenly interested in companies' activities, particularly in encouraging exploration of the deep potential of the UKCS, leading for example to successes in the Southern North Sea. Similarly, his enthusiasm for coring contributed to the collection of what is an invaluable national rock resource. His memorable Cambrian oolite play
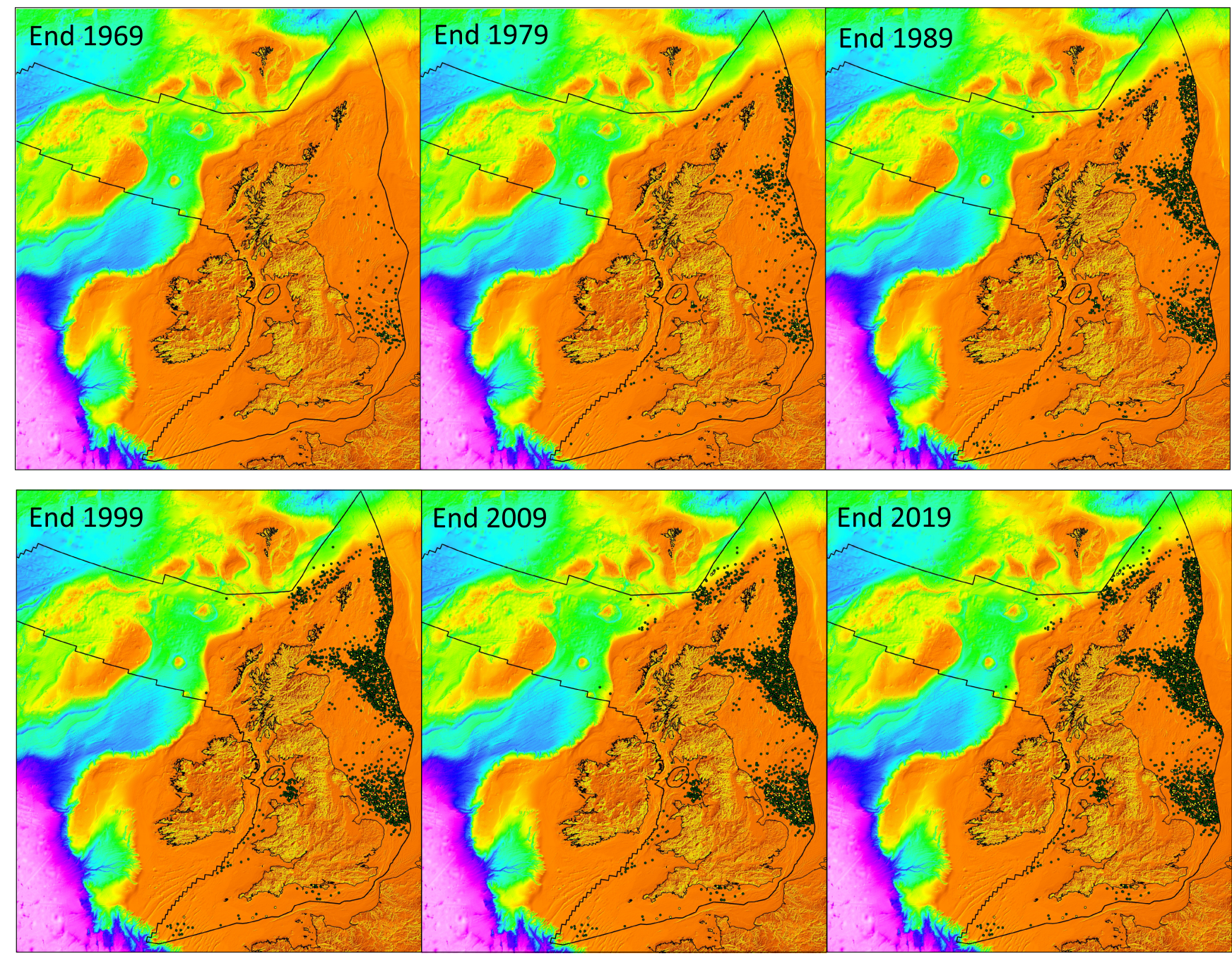

Fig. 1. The cumulative evolution of exploration and appraisal drilling on the UKCS, by decade, from the end of 1969 to the end of 2019 . Exploration wells are shown in green, appraisal wells in yellow. Coloured bathymetry from GEBCO Bathymetric Compilation Group (2019).

From: Goffey, G. \& Gluyas, J. G. (eds) 2020. United Kingdom Oil and Gas Fields: 50th Anniversary Commemorative Volume.

Geological Society, London, Memoirs, 52, 3-18, https://doi.org/10.1144/M52-2019-48

(C) 2020 The Author(s). This is an Open Access article distributed under the terms of the Creative Commons Attribution License (http://creativecommons.org/ licenses/by/4.0/). Published by The Geological Society of London. 
Downloaded from http://mem.lyellcollection.org/ by guest on October 29, 2021

concept ('Courageous risk takers needed': Whaley 2005) remains as yet untested, but reminds us of the pioneering spirit that was especially prevalent during the early exploration of the UKCS when well penetrations were sparse and seismic data mediocre.

Prior to offshore exploration and production in the UK, Norman Falcon and Percy Edward (Sir Peter) Kent wrote the Geological Society's Memoir 2 (1960), Geological Results of Petroleum Exploration in Britain 1945-1957, which reported on the post-World War II period in which a couple of new fields were added to the existing handful of fields in the East Midlands basin. Exactly 60 years and 50 Memoirs later, this Memoir 52 contains papers that include fields in the East Midlands but also papers that record some of the earliest offshore fields through to the most recent fields brought into production.

The first 25 years of the more than 50-year history of offshore exploration and production were recorded by Ian Abbots' Memoir 14: UK Oil and Gas Fields: 25 Years Commemorative Volume. This Memoir was issued in 1991 and contained papers on all 64 of the then-producing UK offshore fields. After a 12-year gap, Jon Gluyas and Helen Hichens co-edited Memoir 20, United Kingdom Oil and Gas Fields, Commemorative Millennium Volume, published in 2003. The three-year lag between the turn of the twentieth century and release of the Commemorative Millennium Volume can perhaps be excused by the amount of work involved in creating a volume with almost 80 papers on 116 onshore and offshore fields. This third volume commemorates the 50th anniversary of the first discovery on the UKCS. Coincidentally it also marks the 100th anniversary of the first deliberate discovery of oil onshore UK, at the Hardstoft 1 well in Derbyshire in 1919. With the first UK offshore gas and oil discoveries having occurred in 1965 (West Sole Field, Southern North Sea (SNS)) and 1969 (Arbroath Field, Central North Sea (CNS)) respectively, again a time lag between the milestones and release of the volume can perhaps be similarly excused by the magnitude of collective work involved in creating this largest volume of the series, with 80 papers on just under 150 fields. As before, this volume is a testament to the willingness of companies and individuals to devote time and effort to sharing scientific knowledge and information with their peers. It also highlights the Geological Society's long-standing contribution, through conferences and publications, to making the UKCS perhaps the most comprehensively published 'science laboratory' of its type worldwide.

The genesis of this third volume arises with the persistent masochism of one of us (JG) in securing Geological Society Publishing House agreement in 2013 for a new UK oil and gas field Memoir. Subsequently, in early 2016, and through a combination of ignorance as to the amount of work involved and a degree of altruism towards the UK industry, notwithstanding having been part of the redundancies of an entire office of people in the 2014/15 oil-price collapse, GG raised with the Publishing House the idea of a third Memoir. It transpired that such a proposal already existed but had not progressed and everyone was happy to see a second editor join the project. The Geological Society's Petroleum Group agreed to badge the project. Much appreciated support was received from Nick Richardson on behalf of the Oil and Gas Authority, Steve Jenkins for the Oil and Gas Independents Association and Ken Cronin at UK Onshore Oil and Gas leading to the issue in June 2016 of the first letters to oil companies soliciting papers for the project.

It took some time to build awareness of and enthusiasm for Memoir 52. In 2016 the industry was bumping along the bottom after the oil-price collapse, many companies were still laying off staff, remaining staff were highly stretched and understandably neither staff nor companies were always willing to commit to the necessary work. But persistence, some degree of oil-price recovery and the historical willingness of many in the oil and gas industry to support such a 'self-help' endeavour increased the level of commitment. Support expanded through 2017 and 2018, with companies revisiting their earlier positions as the memoir gained momentum. Support came from companies on all scales. Inevitably some of the very largest companies were major contributors of papers; Shell and Total being especially prominent in providing seven papers each. But smaller companies also played a significant role, reflecting one of the substantial changes in the basin since the 1991 and 2003 Memoirs. The first paper David Offer's paper on Juliet Field - was submitted in May 2017, whilst the last paper was accepted in December 2019.

\section{Organization of this Memoir}

The field papers in this Memoir (Fig. 2) are organized by basin/area and this introductory paper follows the same sequence in discussing the papers on a basin-by-basin basis:

- Onshore UK

- Southern North Sea

- East Irish Sea

- Central North Sea

- Moray Firth

- East Shetland Basin and Viking Graben

- Atlantic Margin

Authors have been working under editorially imposed limits in terms of paper length and number of illustrations, although additional figures and tables can be found in the Supplementary material included with a number of papers. Authors have also been working within a common paper structure in order both to facilitate reader access to data and information and to guide the relatively large number of authors who had not previously published in the geological literature. Any shortcomings in this structure are, of course, the responsibility of the editors. The structure is organized under the following, common headings.

History of exploration and appraisal: typically, a brief history of discovery and insights gained through the exploration and appraisal (E and A) phase.

Development: typically, a brief summary of the planned and actual development with more detail on the evolving history of development/production contained in a later section of the text.

Regional context: generally, this summary-level section touches on basin evolution and the main petroleum system elements but to the extent that this is a literature compilation rather than original work, authors were encouraged to keep this section relatively short.

Database: this is an additional section relative to the 2003 volume and was designed to allow readers to understand the specific database available on the subject field, given the many changes in nature and quality of data which have been gathered over the long life of some fields in this Memoir. Authors were encouraged, in particular, to comment on the use of 3D technologies where seismic has allowed improved reservoir and/or hydrocarbon characterization to guide development, whether addressed here or in other sections of the text.

Trap: this section describes the various elements of the trapping geometry and sealing elements. It may also include, for example, evidence of compartmentalization, fluid contacts and the impact of trap geometry on field development.

Reservoir and petrophysics: typically, a major text section describing observed lithofacies, reservoir diagenesis, interpreted depositional environments and reservoir geometries, 
Downloaded from http://mem.lyellcollection.org/ by guest on October 29, 2021



Fig. 2. UKCS petroleum basins and fields showing fields addressed by papers in this Memoir. Boxes show the outline of detailed maps contained in the front and end papers to the Memoir. 
Downloaded from http://mem.lyellcollection.org/ by guest on October 29, 2021

poroperm characteristics and controls, any specific petrophysical challenges and insights from pressure data.

Production history and reserves: this section reports on the field's dynamic performance, understanding gained through the production history and how that understanding has informed ongoing development. A few undeveloped fields are included in the Memoir and, in these cases, this section normally comments on expected hydrocarbon recovery, resource and recovery uncertainties and reasons for lack of development. The editors feel that documenting undeveloped pools is as valuable as documenting developed fields, hence the inclusion of such fields in this volume.

Field data summary: a tabulation of key quantitative data regarding each field and frequently major sub-reservoirs or segments within a defined field.

\section{Sources of additional data on UK oil and gas fields}

Appendix A to this Memoir lists all the UK fields onshore and offshore that have produced oil and gas, in addition to a nonexhaustive listing of fields that had not been put into production at the time of writing (end 2019). It also provides a comprehensive suite of references for published papers and other relevant published documents, such as cessation of production reports, on each field. It is hoped this reference database, which substantially expands upon a similar listing in Memoir 20, will prove useful to readers. The main literature sources are the preceding Memoirs to this one, Memoir 14 and Memoir 20, in addition to the proceedings from the Petroleum Geology Conference (PGC) or 'Barbican' conference series on the Petroleum Geology of Northwest Europe. Of the eight proceedings' volumes, only the first three were not published by the Geological Society and Appendix A includes papers from the 6th, 7th and 8th PGC conferences, published in 2005,2010 and 2018 respectively, and thus post-dating Memoir 20.

\section{Setting the scene and key themes}

By way of scene-setting, King (2020) looks back on more than 50 years of history of the North Sea basins, whilst Rouillard et al. (2020) examine the discovery history of the UKCS basins, with creaming curves and discovery volumes from first drilling in 1965. In addition to the inevitably increased number of small field developments, the editors have recognized a number of prevailing themes that emerge from the collection of papers in this Memoir, some of which are briefly summarized below, before the papers are then discussed by basin.

- The increasing instrumentality of seismic data: this theme was, of course, expected and authors were specifically invited to discuss seismic applications in their oil and gas fields. Papers in this Memoir demonstrate the use of seismic data to assess lithology and fluid fill through the life cycle. In the early stages this includes de-risking and resource quantification in small pool, infrastructure-led exploration (e.g. Brechin Field) and in field development (e.g. Catcher Field). In later stages it includes the identification of additional resource outside of perceived field limits and for well planning purposes during field redevelopment (e.g. Donan and Shearwater fields), through to $4 \mathrm{D}$ understanding of hydrocarbon and waterflood movement allowing low-risk infill drilling in late field life (e.g. Forties Field). That said, it is also noteworthy how many developed fields in late life are still mapped only on relatively old 3D data.
- Multiple strategies of late-life recovery: many fields in this volume have been in production for two or more decades and are sufficiently mature that they are in relatively advanced stages of maximizing late-life recovery. Typically, of course, this involves infill drilling for unswept oil, which may be located using 4D seismic data (e.g. Forties Field) or drilling to access previously undrained compartments (e.g. Sean Field). But Captain Field is undergoing chemical enhanced oil recovery (EOR) via polymerized water injection, whilst water-alternating-gas (WAG) injection has been piloted at Douglas Field. By contrast, in the main chalk reservoir of Machar Field, pressure support from injected water imbibition drive has now ceased in favour of solution gas drive to maximize liquids recovery before increasing permeability to gas leads to a gas-dominated final blowdown.

- Evolution in drilling and completion technologies: there is nothing new in this theme but the historical look-back which this volume affords provides insights into the sustained impact of advances in drilling and completion technologies. To present standards, some of what were for their time remarkable, ground-breaking engineering achievements, such as the 1970s wave of field developments in the East Shetland Basin, now appear remarkably crude. Due to technical limitations at the time, most of the development drilling was of limited step-out from the platforms, with near-vertical trajectories through the reservoir and very basic well completion strategies. For example, NW Hutton had no planned water injection wells (all injectors were re-purposed production wells) and managed to recover only $16 \%$ of the oil in place. By contrast, a modern, multi-reservoir field development such as Golden Eagle and its satellites deploy multiple independent zonal completions, zonal downhole monitoring of pressure, temperature and flow, supplemented by inter- and intra-well tracers and interference testing. These allow the independent control of dozens of production and injection intervals to optimize field recovery.

- The growth of field re-development: the re-development of old fields was in its infancy when the 2003 Memoir was published, whereas in this Memoir there are a number of re-developed fields. These include wholly new developments of abandoned fields, such as Donan Field, which was redeveloped as the Dumbarton Project, and Alma Field, which was developed and abandoned twice, as Argyll and then as Ardmore Field. There are also fields that have been temporarily suspended whilst facilities are changed and new wells drilled (e.g. Shearwater, Schiehallion and Loyal fields) or whilst fields are 're-plumbed' to a new host (e.g. the recently sanctioned Penguins re-development). The relatively inefficient drainage of certain older fields, as a consequence of factors including technological limitations (seismic imaging, drilling, completions), inadequate geological understanding and/or facilities limitations (e.g. water injection, water handling) offers the scope to extract a commercial volume through re-development. This theme is well illustrated in the East Shetland Basin, where a number of fields have relatively low recovery and, for example, NW Hutton Field is under evaluation as a re-development.

- New exploration targets: new discoveries that post-date the 2003 Memoir include new reservoirs not previously found to host commercial fields, and a range of relatively complicated, hard to image or subtle trapping styles and geometries in established reservoirs. For example, in the CNS 'inter-pod' play, Cayley, Godwin and Shaw fields are trapped in a series of cryptic downthrown and/or stratigraphic traps where the Fulmar Formation (Fm) appears to onlap Triassic strata on the Forties Montrose High. In the 
Moray Firth, the Golden Eagle Field is a predominantly stratigraphic trap by depositional pinchout of a ribbon-like channelized Jurassic sandstone. In the SNS, following older discoveries with an element of stratigraphic trapping, the various compartments of Wingate Field are trapped by base seal and side seal at several different levels within the Westphalian stratigraphy. In newly established reservoirs, the UK's first basement-reservoired field, Lancaster, in the Atlantic Margin, was found by following-up a 1970s well that encountered oil shows in a limited basement penetration. Lancaster Field has just commenced production. Similarly, in the SNS, both Cygnus and Breagh fields were found by appraisal of relinquished discoveries that had originally flowed at non-commercial rates. Surely these will not be the last North Sea fields to be discovered by re-evaluation of old wells. Cygnus is the only field producing gas from a Leman Sandstone reservoir on the northern margin of the Silverpit lake. Breagh Field produces gas from Visean clastics, the oldest productive reservoir in the SNS, in an area where the source rock must be appreciably older than the traditional Westphalian coals.

- The emergence of remobilized sandstone reservoirs: in Memoir 20 only the Eocene sandstone reservoir at Harding Field (Beckly et al. 2003) was recognized as having experienced major sandstone remobilization, although injected sandstones had been recognized for some time in wells in the CNS. A growing awareness of this type of reservoir was marked in the early 2000s, for example, by an appraisal campaign at Volund Field in Norway, predicated on a sandstone injection model for reservoir development (Satur et al. 2017). The subsequent growth in awareness and understanding of remobilized (injected and extruded) sandstone reservoirs on the UKCS, and their scope to host commercial pools, is marked in Memoir 52 by extensive discussion and analysis of remobilized sandstone-reservoired fields. This is the case both in late-life fields such Gryphon and Chestnut, as well as in new developments such as Mariner, Catcher, Burgman and Varadero fields. The emergence of remobilized sandstone reservoirs as commercial exploration targets in their own right is perhaps the most significant new play development revealed by papers in this Memoir.

\section{Onshore UK}

The UK's first commercial gas field onshore UK was discovered accidentally at Heathfield in the Weald Basin in 1895, when a water well and several deliberate follow-up wells encountered gas (Dawson 1898), which was used for many years to light the Heathfield railway station, street lights and houses in the village (Fig. 3). The UK's first deliberate oil find was made immediately following World War I. The 1919 Hardstoft 1 discovery was made in the Derbyshire part of the East Midlands basin and produced $45000 \mathrm{bbl}$ until it ceased production in 1945 (Craig et al. 2018). The Carboniferous basins of the East Midlands host a number of relatively small fields, a number of which were discovered between the 1930s and 1960s, and have since ceased production. These fields are significant as they provided part of the impetus for the first move offshore in the 1960s, thereby commencing the more than 50-year offshore exploration and production history that serves as the backdrop to papers in this Memoir. It is appropriate then that this Memoir contains papers on fields in both the Weald and East Midlands basins.

Despite being small in size, owing in part to wartime demand, some of the earliest East Midlands fields (Lees \& Tait 1945) were developed via intensive drilling, for example Eakring-Dukeswood (197 wells) produced 6.5 MMbbl of oil (Storey \& Nash 1993). Following a change in licensing

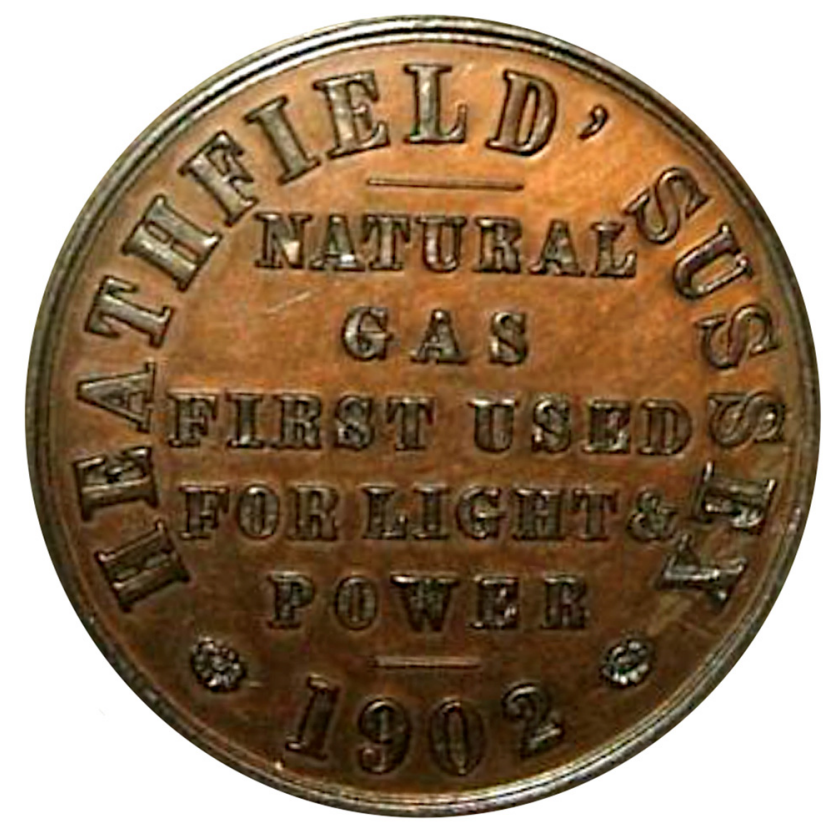

Fig. 3. Reverse side of medal which was struck to commemorate the coronation of King Edward VII in 1902 and was distributed to school children in Heathfield on Coronation Day. The striking of the medal was funded by Natural Gas Fields of England Ltd, a company that was wound up in 1905 amid suspicions of fraudulent activity (Sturt 1993). [From the collection of Graham Goffey.]

terms and oil price improvement, a rejuvenation of activity in the 1980s led to many more relatively small pools being discovered by BP and others (Candy 1983). Ward \& Folorunso (2020) provide an overview of a number of the East Midlands fields. Of the later discoveries, Welton Field is the largest, having produced around $20 \mathrm{MMbbl}$. A small example is the 1986 Crosby Warren Field, described by Johnson \& Evans (2020). Sparse 2D coverage over this $0.9 \mathrm{MMbbl}$ field meant unexpected deviations from prognosis in production well side-tracks; such is the relatively 'low tech' approach enforced by limited remaining commercial value. Crosby Warren lies adjacent to the relatively recent Wressle discovery. In a sign of the changing industry context, almost six years after discovery, planning permission has yet to be secured to develop Wressle, in an area of the country where oil and gas activity has been going on intermittently since the first half of the twentieth century. In the Weald Basin, Gluyas et al. (2020a) describe the Humbly Grove gas storage field and its satellite fields, Herriard and Hester's Copse. The small (6 MMbbl) Humbly Grove oil field, reservoired in the Middle Jurassic Great Oolite Group (Gp), was converted to gas storage after a 16-year oil producing life. Gas injection and re-pressurization have mobilized a portion of the residual oil in place, leading to renewed oil production from the field, in a form of EOR that adds to the commercial value of the gas storage service.

Papers on both Elswick and the Vale of Pickering onshore gas fields are discussed in this Memoir with the offshore basins to which these onshore fields belong, namely the East Irish Sea and SNS, respectively.

\section{Southern North Sea and onshore Cleveland Basin}

The three main reservoir intervals in the SNS, of Carboniferous, Permian and Triassic age, are all represented in this publication. A number of the reported fields would perhaps be considered to be more difficult to appraise and develop than many of those reported in the earlier Memoirs. Development 
challenges in many of these later-developed fields include small size, low reservoir permeability, compartmentalization (not always evident prior to development) and in the Carboniferous-reservoired fields, reservoir subcrop, fluvial reservoir extent and connectivity.

In two papers, Hook $(2020 a, b)$ reports on one the earliest SNS discoveries, Hewett Field, and its multiple satellite fields, which have in aggregate produced some 4.4 tcf. Discovered in 1966 and with a 50-year production history, the principal reservoirs are the Triassic Bunter Sandstone Fm and Permian Zechsteinkalk Fm in the main field, and Rotliegend Gp in the satellite fields. The history of these fields reveals a relatively high failure rate in development wells as a result of unresolved depth conversion and seismic imaging issues arising from seismic data limitations in the early decades of the field's exploitation. The Bunter Sandstone Fm is a relatively minor gas reservoir in the SNS but is recognized as a potentially sizeable reservoir for $\mathrm{CO}_{2}$ storage (Bentham 2006). Gluyas \& Bagudu (2020) describe the Endurance candidate $\mathrm{CO}_{2}$ sequestration site. Endurance lies $50 \mathrm{~km} \mathrm{SW}$ of the abandoned Esmond, Forbes and Gordon fields in the Bunter Sandstone Fm reservoir and was appraised and tested for $\mathrm{CO}_{2}$ injection in 2013. However, the removal by government of funds to establish $\mathrm{CO}_{2}$ sequestration led to the project being terminated post-appraisal. Carbonates in the Zechstein $\mathrm{Gp}$ are also minor reservoirs in the SNS and its onshore extension, the Cleveland Basin. In the latter, Harrison et al. (2020) discuss a number of fields in the Vale of Pickering, reservoired in the Kirkham Abbey Fm of the Zechstein Group (Z2 cycle), equivalent to the Hauptdolomit Fm offshore. Production from these small fields has been limited by excessive water production associated with natural fractures.

The Viking complex of fields, described by Anston-Race \& Ganesh (2020), was another one of the earliest discovered Permian Rotliegend Gp fields, found in 1965. The complex was developed in two phases between 1971 and 2000 with cessation of production in 2015 after production of around 3.3 tcf. Botman \& van Lier (2020) demonstrate the late life development of another relatively old Rotliegend-reservoired field complex: the Sean Fields. Discovered in 1969 and developed in 1986 the fields were acquired by ONE-Dyas in 2015. Additional development drilling into a partially depleted field compartment, coupled with investment to reduce operating costs and install compression, have enhanced ultimate recovery and extended field life.

From the perspective of new Rotliegend-reservoired fields, Miles et al. (2020) report on Tolmount Field, a significant, recent (2011) Leman Sandstone Fm discovery lying under a complexly faulted shallow overburden. Dredge \& Marsden (2020) review Cygnus Field, which is probably the largest new SNS field in recent years. Cygnus is, exceptionally, located on the northern margin of the Silverpit Fm lake whereas all other developed Rotliegend Gp fields lie in the typically aeolian-dominated reservoirs found on the southern side of the lake. Appraisal drilling on an old, relinquished discovery made in poor quality, fluvial Leman Sandstone Fm established the presence in this large structural trap of both better-quality Leman Sandstone reservoir and reservoirs in Westphalian C Ketch sandstones.

At the southern edge of the Rotliegend Gp, Silverpit Fm lake, Carrack Field (Rieu \& Porter 2020) produces mainly from sandstone reservoirs within an alternating interval of distal fluvial sandstones and silty mudstones of the Silverpit Fm, both lithofacies showing evidence of haloturbation indicative of a playa mudflat setting. Further NW, Babbage Field (Phipps \& Tiltman 2020) is a mainly fluvial Leman Sandstone Fm reservoir with much higher net/gross ratio (NTG) than Carrack but with low permeability due to the development of pore-filling illite during deep burial. Here, artificial fracturing of the production wells has enabled a commercial field development. Verlinden \& Basford (2020) describe Ensign Field, another similarly low-permeability, deep-buried Rotliegend-reservoired field that was developed via artificial fracturing of production wells. Here however, the presence of so-called 'Dekeyser' fault zones (e.g. van Ojik et al. 2019) transecting the field have compartmentalized the accumulation to the detriment of ultimate recovery. The Juliet Field (Offer 2020) similarly indicates some of the challenges associated with developing Rotliegend Gp pools, with depth conversion issues and, as with Ensign Field, unforeseen fault compartmentalization detrimentally impacting the resource volumes in an already small accumulation.

In addition to Cygnus Field, a number of other fields described in this Memoir are reservoired in Westphalian Ketch sandstones. At Wingate Field (Huis in 't Veld et al. 2020) the trap geometry is a complex mosaic of upthrown and downthrown fault blocks, partially stratigraphic in nature, with base seal and downthrown fault seal variously provided by Westphalian D, B and A mudstones. At Grove Field (van Oorschot et al. 2020a), a more straightforward structural trap was developed with high angle wells. Complexities arising from intra-field faulting and variable erosion at the Base Permian unconformity (BPU) have meant highly variable productivity per well. This is a common issue in Carboniferous fields, with the limited areal extent of isolated fluvial sandstones being another factor limiting per well recovery. Ketch, Schooner and Topaz fields (Moscariello \& Goffey 2020) exemplify this issue of compartmentalization through reservoir extent in the Ketch sandstone reservoirs, locally exacerbated by Dekeyser faults. For example, at Schooner Field, a single well produced $130 \mathrm{bcf}$ whilst the average recovery of the remaining ten wells was 18 bcf.

Engineering mitigation of reservoir extent/connectivity and productivity issues is demonstrated in several Carboniferous fields. For example, at Chiswick and Kew fields, which produce from multiple, low permeability stacked fluvial sandstones of Westphalian A and B age. Here, Smit (2020) describes horizontal, artificially fractured wells, which have permitted a commercial development through maximized reservoir access and enhanced well productivity. Milner et al. (2020) explain how Kilmar Field has been developed via high angle, multi-bore wells. These maximize reservoir access from stacked Namurian to Westphalian A sandstones subcropping the BPU in a structural trap enhanced by intraCarboniferous seal. Cavendish Field (Wasielka et al. 2020) is primarily a Westphalian A-reservoired field, with structural closure at the level of several intra-Carboniferous seals, but not at the level of the traditional base Permian top seal. In contrast to Chiswick Field, here some $85 \%$ of field recovery was from a single, high-quality Westphalian A quartzitic sandstone body, with minimal recovery from several other Westphalian A and Namurian fluvial sandstones. With a relatively high non-hydrocarbon gas content, the availability of blend gas to dilute the non-hydrocarbon content allowed a commercial development to take place at Cavendish.

The substantial Breagh Field (Nwachukwu et al. 2020) has the oldest productive SNS reservoir since it produces gas from Early Carboniferous (Visean) Yoredale Fm clastics. The field was a 1997 discovery that flowed at non-commercial rates but was successfully re-drilled in 2007 on the correct premise that reservoir damage had prevented commercial flow rates in the original well. There are likely to be other such pools where modern drilling and completion practices can permit the development of fields considered to be non-commercial for reasons of low productivity or of resources dispersed between multiple stacked reservoirs. Similarly, issues with excessive $\mathrm{CO}_{2}$ content, apparently associated with Tertiary dykes 
(Brown et al. 1994), can be addressed technically through offshore $\mathrm{CO}_{2}$ removal via membrane separation. This technology has yet to be deployed in the SNS to permit the development of a number of stranded gas pools.

\section{East Irish Sea and onshore West Lancashire Basin}

Following the discovery and development of the Morecambe Bay gas field complex, the East Irish Sea Basin was seen as a gas province, although as far back as the seventeenth century oil seepages had been described onshore at Formby (Lees \& Tait 1945). The shallow Formby oilfield produced more than $70000 \mathrm{bbl}$ of $37^{\circ} \mathrm{API}$ oil between 1939 and 1965 from Triassic and Pleistocene reservoirs sealed by Pleistocene boulder clay and Holocene peat (DECC 2013). Bunce (2020a) reports on the first offshore oilfield discovered in the basin: Douglas Field, found in 1990. Again, a remarkably shallow field, with top reservoir at just over $2000 \mathrm{ft}$ TVDSS (true vertical depth subsea), it contains $44^{\circ}$ API oil. Now a relatively mature field, a recent immiscible WAG-enhanced oil recovery pilot project shows some encouragement for additional recovery. The adjacent Lennox oil and gas field (Bunce 2020b) is also mature, having produced more than $50 \%$ of its oil in place, and is now in an advanced stage of blowdown of the gas cap. Patroni Zavala et al. (2020) report on Rhyl Field, a more typical Triassic-reservoired gas field. Their paper illustrates the challenges of seismic imaging and depth conversion below velocity anomalies associated with the Tertiary Fleetwood Dyke Complex, in addition to the complexities of handling the non-hydrocarbon gas content associated with these dykes. Finally, the tiny Elswick Field located onshore on the Fylde peninsula (Hampson et al. 2020) is the only producing field in the basin reservoired in the Permian Collyhurst Sandstone Fm, the productivity of which was enhanced by a $\mathrm{CO}_{2}$ fracture stimulation. With a high nitrogen content, again likely due to the field's proximity to Tertiary dykes, the 0.5 bcf of gas produced was used for on-site electricity generation.

\section{Central North Sea}

\section{High-pressure-high-temperature fields}

The production history of the first-developed high-pressurehigh-temperature (HPHT) discovery, Erskine Field, is updated by Robertson (2020). The Jurassic reservoirs of Erskine have now produced over $350 \mathrm{bcf}$ and $70 \mathrm{MMbbl}$ condensate, although the field has had several long production outages due to pipeline rupture, leaking condensate, wax-related flow assurance problems and scale deposition. Taylor \& Jones (2020) describe how problems related to development wells also caused a six-year outage on Shearwater Field, in this case well failures due to casing collapse. The re-development of Shearwater was assisted by seismic indications of hydrocarbon presence in the main Jurassic, Fulmar Fm reservoir, with 4D data assisting in reservoir management. 4D data have also assisted in understanding the compaction and vertical stress changes in the reservoir and overburden (which were responsible for casing collapse), and in predicting pore pressure for well design purposes. 4D data have been similarly utilized in the Elgin, Franklin, Glenelg and West Franklin fields, the world's largest HPHT development, described by Irving et al. (2020). As with Shearwater, production wells were planned to be drilled prior to significant depletion of the Fulmar Fm reservoir but advances in drilling technology have allowed the drilling of later infill wells despite depletion in excess of 8700 psi. The complex has to date produced 886 MMboe of an expected 1300 MMboe.

Jasmine Field is one of the more recent HPHT field developments, producing first gas in 2013, in this case from fluvial sandstones of the Joanne Sandstone Member (Mbr) of the Triassic Skagerrak Fm. In contrast to the more tank-like behaviour of the Fulmar Fm HPHT reservoirs, Lawrence et al. (2020) report that the Triassic reservoir showed the expected low vertical permeability due to layering, but more rapid production decline, poorer connectivity and lower deliverability than anticipated. In attributing these aspects of reservoir performance to structural heterogeneities in particular, Lawrence et al. compare the production performance of Jasmine with that of Jade and Judy fields and other potentially analogous Triassic-reservoired Central Graben fields. Lastly, Nygaard et al. (2020) report on the most recent HPHT field development: Culzean Field, reservoired in Middle Jurassic Pentland Fm and Triassic Joanne Sandstone Mbr. The extensive and well-published experience of HPHT field production and reservoir behaviour of the Triassic reservoirs is considered by Nygaard et al. in their description of the Culzean Field reservoir as it was understood following initial development drilling and on the cusp of first production. Recovery of some 250-330 MMboe is anticipated.

\section{Salt diapir fields}

The Zechstein salt diapirs of the Central Graben host fields both on the flank of piercing diapirs (e.g. Pierce North and South, Mungo, Machar and Merganser fields) and on the crest of salt pillows and diapirs which do not pierce the reservoir (e.g. Lomond, Scoter and Starling). In the first category, two fields are on a late field life depressurization trajectory. Sayer et al. (2020) outline the latest stage of development of Machar Field, one of very few chalk-reservoired fields on the UKCS. Machar Field produces oil with a relatively high gas:oil ratio (GOR) mainly from a fractured Late Cretaceous and Paleocene chalk reservoir with low matrix permeability, under an imbibition water drive mechanism with carefullymanaged water injection. In February 2018 water injection was ceased in favour of solution gas drive; a mechanism that should initially allow enhanced oil recovery before gas production becomes dominant. Few UKCS reservoirs have undergone such a hard-to-model process, Brent (Christiansen \& Wilson 1997) and South Brae (Drummond et al. 2001) fields being the main prior examples. Consequently, there is a considerable uncertainty as to the likely liquids recovery from this phase at Machar Field. Hale et al. (2020) describe the twin-diapir Pierce Field. Producing from Paleocene Forties Sandstone Mbr sandstones, the oil legs of the field were initially developed with gas re-injection to maintain pressure, then further developed with water injection and a phase of infill drilling. Topsides gas-handling limitations mean that presently reservoir management is dominated by GOR optimization, but the field is shortly to commence a depressurization phase with gas export.

Gas is the main reservoir phase in several Central Graben diapir fields. Having produced some 880 bcf to date, Lomond Field is one of the larger gas condensate fields reservoired in Paleocene sandstones (Forties Sandstone Mbr, Lista, Andrew and Maureen formations). Jena \& Olowoleru (2020) describe the apparent structural compartmentalization of the field, with a common pressure regime in the gas leg but several fault-bounded compartments, each with their own gas-water contact (GWC) and aquifer pressure gradient. The authors observe that the field behaves essentially as a single tank and the varying contacts are attributed to fault hydrodynamic seal, preventing aquifer pressure equalization. The Merganser, 
Scoter and Starling diapir fields are described by Freeman et al. (2020). These fields produce mainly, in the case of Merganser, or exclusively, in the case of Scoter and Starling fields, from the Paleocene Forties Sandstone Mbr. At Merganser and Scoter, varying GWC levels and pressure regimes have been encountered around the field, with ambiguity as to whether this is related to radial faulting, a tilted contact or capillary effects. In the thin gas-condensate and oil-bearing Andrew Sandstone Mbr reservoir at Stella Field, Wright et al. (2020) describe the surprising outcome of one of the development wells in terms of hydrocarbon phase and contact; attributed to compartmentalization of the field by radial faulting. Stella has a secondary reservoir in chalk of the Ekofisk and Tor formations, better reservoir development of the former being indicated by low seismic acoustic impedance at the structural crest. Mungo Field is a piercing diapir that has produced around $180 \mathrm{MMbbl}$, mostly from the Paleocene Forties Sandstone Mbr reservoir. In addition to an update on the field, Baniak et al. (2020) provide a new description of its little-penetrated and essentially undeveloped Chalk Fm reservoir, drawing attention to the remaining resource potential in this interval. Given the steep dip and relatively thin reservoirs at Mungo Field, 3D data have been of limited utility for lithology and fluid prediction.

\section{Fields with reservoirs in the Forties Sandstone $\mathrm{Mbr}$}

Rose et al. (2020) summarize the 45-year production history of the UK's largest oil field: Forties Field, with 2.75 Bbbl produced from 1975 to date. The recent Forties Field history documented by Rose et al. is a case example of the impact of a change of operator and of strategy, coupled with technological development. Following Apache's acquisition of a mature field from BP, major drivers of infill drilling have been the further development of the use of amplitude v. offset (AVO) attributes to discriminate lithology and generate infill targets, and the use of 4D surveys, coupled with continued improvement in seismic data quality. The outer parts of the field have essentially been redeveloped through these approaches and more than $170 \mathrm{MMbbl}$ have been developed since the Apache acquisition in 2003. Similarly dependent on seismic attributes to reduce both exploration risk and volumetric uncertainty, Goffey et al. (2020) describe the discovery and development of the Brechin Field, a 7 MMbbl confined, channel-fill sandstone reservoir tied back to the MonArb complex. Couch et al. (2020) detail the Huntington Field, located some $20 \mathrm{~km}$ to the north of Brechin Field. Here, much of the oil is retained within unconfined, lobate, turbidite sand-sheets deposited on top of the earlier confined channel-fill sandstones but separated from the channel fill by regionally extensive thin mudstone layers. The consequent low vertical permeability contributes to limited aquifer bottom-water drive and is one of several factors limiting oil recovery. Finally at the distal end of the Forties fan system, Robertson et al. (2020a) report on Blane Field, observing that varying oil-water contact (OWC) levels, despite a common hydrocarbon gradient in the exploration and appraisal wells, could be taken as indicative of either fault compartmentalization or a hydrodynamically tilted OWC. Production data and history matching indicate that the latter model is now preferred.

\section{Fields in Triassic 'pod' and Jurassic 'inter-pod' reservoirs}

A cluster of Fulmar-reservoired, small to medium-sized fields on and around the Forties-Montrose High (FMH) are trapped in downthrown and/or partially stratigraphic traps in so-called 'inter-pod' settings. These are Jurassic troughs typically lying above deflated Zechstein salt bodies between large-scale Triassic 'pods' or salt withdrawal mini-basins (e.g. per Karlo et al. 2014). Howe and Bardolino fields are described by Liebnitz (2020); both are downthrown against and basesealed by Triassic strata flanking the FMH. Bardolino has proven to be compartmentalized, possibly by cataclasis along fault(s) of modest throw. A broadly similar trapping geometry is displayed by a string of fields in Fulmar Fm reservoirs on the FMH and along its western side: Wood, Cayley, Godwin and Shaw. Here, Baldwin (2020) characterizes the slightly ambiguous trapping geometries that hold parallels with trapping in Howe and Bardolino fields. Wood, Godwin and Shaw fields appear in the critical updip direction to be either stratigraphically trapped against Triassic strata of the FMH and/or downthrown against the Triassic section. Although Cayley Field is a complexly faulted anticlinal structure, a Triassic base-seal is similarly invoked here. Further south, Hagen et al. (2020) describe the undeveloped Acorn and Beechnut accumulations. Beechnut is a Fulmar Fm stratigraphic trap in an inter-pod setting, with post-depositional erosion leading to reservoir truncation towards the adjacent Triassic pods. Pressure and geochemical data suggest a compartmentalized pool. Acorn, by contrast, occupies the crest of a Triassic 'pod' - a Triassic salt-withdrawal mini basin capped by Skagerrak Fm sandstone reservoir. Development has been precluded by long-term well test data suggesting limited reservoir connectivity in this relatively low NTG fluvial sandstone reservoir. Birgitta Field, east of the FMH, occupies a similar setting to Acorn and is similarly reservoired in the Skagerrak Fm, in this case the Joanne Sandstone Mbr. Here, Goffey (2020) makes use of published local analogues to infer several specific challenges that need to be considered in appraisal and development of this near-HPHT accumulation.

\section{Other Central Graben fields}

Remobilized sandstone reservoirs are described by several authors in this Memoir, with Chestnut, Catcher, Varadero and Burgman fields being examples in the Central Graben. Chestnut Field is described by van Oorschot et al. (2020b). At Chestnut, the extent of the injected Eocene sandstone reservoir was not fully recognized at first production in 2008. Shear wave seismic data and elastic attributes together assist in field definition but many of the re-mobilized sandstone geometries are poorly imaged or not imaged on 3D data, leading to considerable uncertainty in reservoir development and connectivity. Initial volumetric estimates were necessarily cautious and during production life the field stock tank oil initially in place (STOIIP) has more than doubled to $66 \mathrm{MMbbl}$. On the Western Platform of the Central Graben, the Catcher, Varadero and Burgman shallow fields hold lightly biodegraded oil, again in Eocene injected sandstone reservoirs. As with Chestnut Field, Gibson et al. (2020) report on the difficulties of mapping and quantifying the complex morphology of injected sandstones, particularly when a portion of the reservoir is below seismic resolution. The Catcher fields came on stream in 2017. Also, on the Western Platform, the Pilot area fields (Pilot, Elke, Blakeney, Narwhal, Harbour and Feugh) are described by Brown et al. (2020). Other than Pilot Field, these shallow, heavy-oil fields are mostly un-appraised, and all remain undeveloped. Reservoir-oil viscosities are comparable with and greater than reservoir viscosities in developed heavy-oil fields reported in this Memoir, for example Mariner Field (Silcock et al. 2020) and Captain Field (Hodgins et al. 2020). Brown et al. argue that oil of this viscosity in highquality, Darcy permeability reservoirs such as are found here 
could be developed with hot water, steam or polymerized water flood. Gluyas \& Arkley (2020) report on Innes Field, one of very few fields outside of the SNS to have been developed in a Rotliegend Gp sandstone reservoir. Finally, and staying with Paleozoic reservoirs, Tang et al. (2020) describe what is probably the only North Sea field to have produced oil under three different names. First known as Argyll, then Ardmore, the present Alma Field was re-developed twice and Tan et al.'s paper, in particular, updates the description of the major reservoir, the Devonian Buchan Fm.

\section{Moray Firth}

The Moray Firth has its fair share of giant fields, of which several now mature fields are reported upon in this volume. Alba Field (Moore et al. 2020) is on track to recover $52-55 \%$ of its nearly $900 \mathrm{MMbbl}$ of heavy (19 $\left.{ }^{\circ} \mathrm{API}\right)$ oil in place through a combination of excellent reservoir properties, horizontal wells and the use of 4D seismic interpretation to optimize well placement and maximize recovery. Further west, Captain Field has a broadly similar in-place resource of $1 \mathrm{Bbbl}$ of shallow, heavy oil $\left(13-20^{\circ} \mathrm{API}\right)$ in unconsolidated sands. Hodgins et al. (2020) discuss the prevalent seismic imaging challenges and the field's development by waterflood using long horizontal, gravel-packed and screened production and injection wells. Following a pilot project, the field is now in EOR mode, with the injection of higher viscosity polymerized water to improve waterflood sweep efficiency and oil recovery. Lying partially beneath Alba Field, the exploitation of Brittannia Field is addressed by Camm et al. (2020). Brittannia is a large gas field, with 4.2 tcf gas in place. Like Captain Field, Brittannia's exploitation has also not been strongly reliant on seismic attributes, although seismic inversion does provide some guide to reservoir development. Understanding and modelling of reservoir characteristics, correlation and geometry have been informed by the collection of an extraordinary $20000 \mathrm{ft}$ of core covering almost all of the reservoir section in some 30 field wells.

A 2020 Memoir on UK oil and gas fields would be incomplete without the largest UK discovery of the twenty-first century, Buzzard Field, which has to date produced some 730 MMbbl. Taylor et al. (2020) demonstrate that the field has proved to have a slightly more complex reservoir architecture and less uniform waterflood sweep than was initially expected. However, increased updip field extent, a deeper OWC and the recognition that seismic prediction of NTG is only locally valid mean that the field follows the old adage that large fields just get larger. Buchan Field (Wynn \& Saundry 2020) is another Moray Firth field that has also continued to get larger with time, in this case through improved matrix recovery from fractured Devono-Carboniferous sandstone. Over the 36 years since first production in 1981, reserves have been continuously upgraded, for example to 67 (1984), 90 (1989) and 100 MMbbl (1991). In fact, the field had produced $148 \mathrm{MMbbl}$ when it ceased production in 2017, with final oil rate and water cut of 2600 bopd and $52 \%$ respectively. The authors demonstrate that there are certainly technically recoverable remaining resources in this field.

At Golden Eagle Field and its Peregrine and Solitaire satellite fields, Pinnock \& Dutton (2020) offer a case example of the use of modern technology in field management in complex channelized reservoirs, using high-fidelity ocean bottom node $(\mathrm{OBN})$ seismic imaging combined with modern completion technology. The latter includes independent zonal completions with sliding sleeves, zonal downhole monitoring of pressure, temperature and flow, inter- and intra-well tracers and interference testing to optimize production and water injection.
The Lower Cretaceous Captain Sandstone Mbr is a prolific reservoir in the Moray Firth, hosting several fields described in this volume. This deep-water, channel-fill reservoir in both Blake Field (Saundry \& Colmenares 2020) and Goldeneye Field (Stewart \& Marshall 2020) contains a thick, high NTG reservoir with permeability up to several Darcys. At Blake Field this channel fill is incised into the older Coracle Sandstone Mbr. The Coracle reservoir is a more heterogeneous, lower NTG package, that holds a much larger oil in place than in the Captain reservoir, but from which a recovery of only $8.5 \%$ is anticipated, compared with $48 \%$ from the Captain reservoir. At Goldeneye Field, the Captain Sandstone Mbr produced some $568 \mathrm{bcf}$ of gas (70\% recovery factor) before cessation of production in 2010. The field was evaluated as a candidate for a UK Government Carbon Capture and Storage (CCS) competition, which subsequently foundered following the unhelpful removal of government funding. Fortunately, the well abandonment design provides for the option to use the reservoir for CCS in the future.

Separate papers by Tegerdine $(\mathbf{2 0 2 0} a, b)$ on the adjacent Renee and Rubie fields describe the development of two small pools on the Renee Ridge. These fields are reservoired in the Jurassic Scott Sandstone Mbr of the Piper Fm and Paleocene Andrew Sandstone unit of the Lista Fm respectively. Ings et al. (2020) describe the nearby Donan Field and its adjacent satellites: Lochranza and Balloch fields. Donan Field produced $15 \mathrm{MMbbl}$ in a short-lived production period in the 1990s and, following re-development as the Dumbarton Project in 2007, remains in production having now produced $59 \mathrm{MMbbl}$ to date. Seismic-derived lithology and fluid discrimination utilizing AVO attributes were key factors in optimizing recovery and recognizing oil trapped outside the apparent field limits. Finally, Allan \& Southwood (2020) describe the undeveloped Perth Field. A 1983 discovery with a $1000 \mathrm{ft}$ hydrocarbon column in Jurassic Claymore Sandstone Mbr reservoir, Perth Field has remained undeveloped due to lack of an export solution for the sour fluids, which contain up to $11444 \mathrm{ppm}$ by volume $\mathrm{H}_{2} \mathrm{~S}$ and $42.2 \%$ $\mathrm{CO}_{2}$. A development now seems to be getting closer, via a processing module adjacent to the Scott Field facility.

\section{East Shetland Basin and Viking Graben}

The East Shetland Basin and North Viking Graben are second only to the CNS in terms of volumetric importance. The large Brent Province fields were amongst the first large oil fields developed on the UKCS, commencing in the 1970s. Papers in this volume demonstrate the nature of these historic field developments and some of the limitations imposed particularly by early seismic imaging, drilling/completion technology and facilities issues during the key development phases. The earliest, field-specific UKCS 3D surveys were acquired here, for example during 1977-79 at Dunlin Field (Ball \& Gluyas 2020), but structural complexity was not resolved on these early surveys and 3D was reshot in later years as 3D acquisition technology advanced.

In the East Shetland Basin, Ball \& Gluyas (2020) describe the discovery and development of Dunlin and the adjacent Merlin and Osprey fields. Here the micaceous, lower shoreface sandstone reservoirs of the Rannoch Fm were less well drained during production than better intervals such as the Etive Fm; however, late in field life an economic case could not be made for long horizontal wells to improve oil recovery from this interval. With appreciable investment needed to address facilities issues, in 2015 the cluster ceased production having recovered 49 (Dunlin), 40 (Merlin) and 36\% (Osprey) of respective oil-in-place volumes. The geology and 
development history of the adjacent Hutton and NW Hutton fields is contrasted by Gluyas et al. (2020b). Due to diagenetic cementation, Brent reservoir quality is shown to generally deteriorate with depth. The shallower Hutton Field recovered around $34 \%$ of more than $500 \mathrm{MMbbl}$ oil in place. Conversely at the deeper NW Hutton Field, where all injection wells were re-purposed production wells and facilities imposed water handling limitations, the field was abandoned at a lower water cut than was Hutton Field, having recovered only $16 \%$ of its $850 \mathrm{MMbbl}$ of in-place resource. Studies are ongoing under the current operator to redevelop NW Hutton as part of the 'Greater Galapagos' complex.

The themes highlighted by Gluyas et al. (2020b) are illustrated in a well-described case history of Pelican Field by Frenz et al. (2020). Here the role of diagenesis in reservoir quality deterioration with depth, the high permeability channelized sandstones in the Ness Fm, the difficulties of waterflooding the Lower Brent reservoirs and the impact of facilities constraints are again well illustrated. Pelican Field is on track to recover only $17 \%$ of its $500 \mathrm{MMbbl}$ of oil in place. The Penguins cluster of fields (Thorpe et al. 2020) were discovered and appraised in the 1970s but not developed until 2003. This complicated suite of pools has four different reservoirs (Jurassic Magnus Sandstone Mbr and Brent Gp, Triassic Cormorant and Statfjord formations) and differing hydrocarbon phases (oil, gas condensate and gas condensate on oil). Recovery factors are relatively low, reflecting depletion drive, compartmentalization, the lack of aquifer support and a number of host issues affecting this long distance $(65 \mathrm{~km})$, co-mingled subsea tieback to Brent Field. A re-development involving a dedicated floating production, storage and offloading vessel (FPSO) was sanctioned in 2018.

Moving southwards into the Viking Graben, Robertson et al. (2020b) and Heath \& Robertson (2020) report on two single well tiebacks: Enoch and Burghley fields. Enoch Field, which contains $37^{\circ}$ API oil in an Eocene Flugga Sandstone Mbr reservoir, was tied back to Brae Alpha platform. The few, early cross-median line fields (e.g. Frigg and Statfjord) each needed a bespoke treaty between the UK and Norway. Enoch was one of several cross-median line fields, another being Blane Field (Robertson et al. 2020a), developed as a result of the implementation by the two governments in the early 2000s of a framework for such developments. Burghley contains $31^{\circ}$ API oil in a low relief, Paleocene Maureen Fm reservoir tied back to the Balmoral Field vessel. Prior to committing to the development, some nine wells were drilled on and around the field, which has expected recoverable resources of just 7.5 MMbbl. By contrast with these small pools, on the adjacent East Shetland Platform, the recent Kraken and Mariner Field stand-alone developments are large accumulations of heavy (13-15 API) oil. Kraken and Kraken North fields (Parkes et al. 2020) are stratigraphic traps in excellent quality, unconsolidated sands. Originally discovered in 1985, the Paleocene Heimdal Sandstone Mbr reservoir could not be imaged on contemporaneous 2D data and the discovery was relinquished. With the benefit of $3 \mathrm{D}$ data and a much-reduced price discount for heavy crude grades, field appraisal commenced in 2007. The much larger Mariner Field (Silcock et al. 2020) is an older discovery, made in 1981, with oil in the Maureen Fm and in the slightly shallower Heimdal Sandstone Mbr which holds more viscous oil than that found at Kraken. The Heimdal reservoir has been extensively affected by post-depositional remobilization and sand injection. Development of both fields is via horizontal wells and hydraulic or electric submersible pumps, and a condensate diluent will be used at Mariner to reduce the crude viscosity for handling purposes.

Remobilized and injected sandstone reservoir is also a key theme in the Gryphon, Maclure, Tullich and Ballindalloch fields comprehensively described by Pelletier \& Gunn (2020). The Eocene Balder Fm reservoir was initially interpreted as having accumulated in a submarine fan lobe depositional setting. With production history, improved seismic data and a renewed geological understanding, sandbodies on various scales cross-cutting the stratigraphy have latterly been recognized as a sand injectite complex which comprises a significant part of the Gryphon reservoir. The trapping mechanism is a complex combination of four-way dip closure of depositional sandstones whilst the intrusive sandstones are now understood to form an intrusive trap above and around the depositional sandstone bodies.

At the southern end of the Viking Graben, Maria Field (Stephens et al. 2020) is a reasonably deep but not HPHT oil and gas field, reservoired in shoreface sandstones of the Fulmar Fm. With hydrocarbons in place of $c .125 \mathrm{MMbbl}$ and $280 \mathrm{bcf}$, issues of compartmentalization and limited well density combined with solution gas drive mean that recovery is currently a relatively low $5 \% / 11 \%$ for gas and oil. Infill drilling is expected to lift recovery to $9 \% / 24 \%$ respectively. Just a few kilometres north, Gluyas et al. (2020c) describe the Morag Field, a carbonate raft of Permian Zechstein Gp lying vertically below the Paleocene reservoir of Maureen Field. This deeper reservoir is fractured dolomite of the Morag Mbr of the Turbot Anhydritic Fm, which produced 2.6 MMbbl from a single well and is one of only a few fields in the Northern Permian Basin to have produced hydrocarbons from the Zechstein Gp.

\section{Atlantic Margin}

The emergence of the Atlantic Margin as a producing province in its own right is reflected by the contrast between the 9 Atlantic Margin fields described in this Memoir and the single field, Foinaven (Carruth 2003), reported in Memoir 20.

In three papers, Clark et al. $(\mathbf{2 0 2 0} a, b, c)$ describe a cluster of broadly similar gas fields. Laggan, Tormore and Glenlivet fields are combined structural and stratigraphically trapped gas-condensate fields in the Flett sub-basin. These fields are reservoired in Paleocene turbidite reservoirs of the Vaila Fm and field extent is informed by a strong seismic response to the presence of hydrocarbons in reservoir. Lying in $600 \mathrm{~m}$ (1970 ft) of water, the Laggan and Tormore fields were developed as a remarkably long-distance subsea tieback via $143 \mathrm{~km}$ multiphase pipelines to Sullom Voe on the Shetland Islands. Some distance to the NE of Laggan-Tormore, the similar Glenlivet Field was jointly developed with Edradour Field, a Cretaceous-reservoired gas-condensate pool located behind the Flett Ridge. Glenlivet and Edradour are subsea developments, also producing into the Laggan-Tormore pipeline. Adjacent to Edradour Field the sizeable (up to $1 \mathrm{tcf}$ ) Glendronach discovery was made in Cretaceous sandstones in 2018, indicating that this complex will be a significant UK gas source for some duration.

Also reservoired in Paleocene sediment gravity flow sandstones, Schiehallion, Loyal and Foinaven fields are the longest producing fields on the Atlantic Margin, discovered in the early 1990s and with a combined STOIIP of $3.6 \mathrm{Bbbl}$. After multiple phases of development drilling, the Schiehallion and Loyal fields (Ward et al. 2020) were produced until 2013. Following replacement of the floating production vessel, a re-development phase has subsequently taken place with production re-commencing in 2017. Schiehallion Field is the poster child for 4D seismic application to reservoir management, holding the record for the number of 4D surveys acquired since the first in 1999.

Rosebank Field (Duncan et al. 2020) is a large four-way dip closure with reservoirs in Paleocene and 
Eocene clastics but by contrast with the Atlantic Margin fields already discussed, these are fluvial and deltaic sandstones separated by extrusive volcanic layers. With good reservoir quality and substantial resources - reported to be in excess of 300 MMboe - Rosebank is moving towards development, as apparently is the Cambo Field $20 \mathrm{~km}$ to the south, where the Hildasay sandstone reservoirs cap the Tertiary volcanics. Horsfall (2020) describes the relatively small Solan Field, an isolated accumulation in relatively shallow water of $135 \mathrm{~m}$ (440 ft) depth in the East Solan Basin. A predominantly stratigraphic trap reservoired in Jurassic deepwater turbidite sandstones, production behaviour has shown a lower degree of reservoir connectivity than expected and consequently, a sub-optimal waterflood sweep.

The Rona Ridge hosts the giant Clair Field (A. Robertson et al. 2020), reservoired in fractured Devono-Carboniferous red bed sandstones and discovered in 1977. Appraisal and development have proceeded in phases, with Phase 1 on stream in 2005. 4D seismic surveys have been important in reservoir management in the Phase 1 fracture-based waterflood. This has been facilitated by progressively improved seismic imaging, with ocean bottom cable (OBC) data, then high density OBC and most recently high density OBN data allowing direct mapping of the reservoir. These improvements in seismic imaging have been key in progressing the second, 'Clair Ridge' phase into development following further appraisal drilling. Production will also be enhanced by low salinity water injection, which is anticipated to recover an additional $40 \mathrm{MMbbl}$ of oil compared to a conventional seawater flood. Oil was produced from fractured Lewisian basement in an early appraisal well on Clair Field and a Clair production well is planned to test this reservoir, which appears closely analogous to that in the Lancaster Field, further SW on the Rona Ridge (Belaidi et al. 2018). Fractured basement is a relatively uncommon reservoir in global terms and the fractured tonalite found here is challenging to petrophysically analyse and to characterize resources and reserves with confidence. Production history from a Clair well, along with that from the early production scheme at Lancaster, will help in understanding the commercial potential in this emerging play.

\section{Closing thoughts}

This volume is published at an important milestone for the North Sea industry. In the last year, two of the very largest companies, Chevron and ConocoPhillips, have departed from the North Sea whilst ExxonMobil are rumoured to be considering their continued presence, having left Norway. These are several of the small number of companies who have been in the basin since the UK's First Licensing Round in 1964. BP, Shell and Total remain active, being particularly focused in and around their key infrastructure positions. The middle ground of independent companies is now rather thin, although Serica, Premier, Cairn, Enquest and a number of others are still active to various extents. Most of the utility companies, which were such active explorers and developers in the 2000s and early 2010s, have also exited. Conversely, new and generally private equity-backed companies have grown rapidly by acquisition of the departees' UK subsidiary companies. Chrysaor, Neptune, Siccar Point and Ithaca have all expanded rapidly in this way. The wave of 'Promote' companies from the last decade has barely recovered post the oil price crash, although a few 'garagistas' are still active and there are always a few new such entrants into each licence round. In these lean times, prospect inventories have been high-graded and, notwithstanding the low level of drilling activity, sizeable discoveries are still being made, in the Atlantic Margin (e.g. Total's Glendronach) and CNS (e.g. CNOOC's Glengorm). Farmout deals are also still being done, for example in 2018/ 19, Cluff farmed out to Shell in the SNS and Soliton Resources to Equinor in the CNS, but the number of such transactions remains low.

Oil price cyclicity and the related peaks and troughs in activity are not new to the North Sea, a relative costly province. However, the wider context to this process of prolonging the life of the basin in its decline phase is a situation where the upstream companies have never collectively been so poorly regarded by the general public. This is the case notwithstanding the general public's more-or-less unwavering appetite for a carbon-intensive, high-emissions lifestyle. Geoscientists working in the industry, especially younger geoscientists, are questioning whether this industry and its dirty perception are for them in the longer term. Geoscience recruitment across the UK in both undergraduate and masters'-level courses has fallen to historically low levels, and sentiment in the investment community is also more negative towards the sector. We would argue that the negative perception is a long way from reality, but the industry has been remarkably poor at explaining and defending its important role during and beyond the energy transition, and the key contribution it can make towards net zero targets.

In common with all industries, the upstream industry absolutely needs to reduce the carbon footprint of its operations and the greenhouse gas emissions under its control, and to work towards net zero targets. A large portion of UK oil and gas consumption is utilized as emissions-producing energy fuel for the consumption of businesses and individuals; the remainder provides plastics, medicines, cosmetics, fertilisers, etc. This latter portion of UK demand is not going to disappear since it is essentially independent of the burning of valuable hydrocarbons for energy. Since the offshore UK sector now only produces just over $60 \%$ of the UK's hydrocarbon demand (OGUK 2018), the remainder is imported, with all of the additional emissions associated with transportation.

The UK oil and gas industry has for many decades provided the country with a cost-effective, secure energy supply, with all the attendant balance of trade, taxation, employment and emissions benefits compared to the importation of oil and gas from distant, and potentially less well-regulated countries. Unless individuals and businesses make the necessary decisions to reduce the emissions intensity of their activities and way of life, the UK will be increasingly reliant on imported fossil fuels. This will be both for the portion of demand that is used other than as an energy fuel and to continue to meet energy demand to the extent that other energy sources cannot be scaled up and commercialized quickly enough in the energy transition. Calls for North Sea exploration to be curtailed disregard both the insufficiency of action to reduce demand and the UK's net importer status for oil and gas. Crimping the UK's declining exploration and production activity is likely to exacerbate rather than reduce the country's greenhouse gas emissions.

It can be said with confidence that in collective terms we know more about the structure and pore space in the subsurface of the UKCS than that of any other offshore area in the world. Because of this knowledge, and the petroleum infrastructure in place, the depleted offshore petroleum accumulations and their adjoining saline aquifers are attractive targets for the permanent storage of anthropogenic $\mathrm{CO}_{2}$. CCS is envisaged in the Paris Accord as a significant part of efforts to decarbonize energy supply and should be a major part of the UK petroleum industry's contribution towards meeting the country's net zero targets. However, progress towards the implementation of CCS in the UK has been glacially slow. CCS offers a trajectory for constructive re-use of many of 
the UK North Sea facilities and the depleted or soon-to-be depleted reservoirs described in this Memoir. It will require the skills, expertise and financial capacity of those companies and individuals that are currently continuing the 50-plus year UKCS oil and gas success story. It should also provide viable businesses and careers for those same companies and individuals. But CCS requires political will to create the fiscal and regulatory regime that is required, and the political decisions that led to the termination of the Endurance and Goldeneye $\mathrm{CO}_{2}$ storage projects described in this Memoir do not set an encouraging precedent. At the time of writing (Q1 2020) the British Government has announced that it will 'invest at least $£ 800 \mathrm{~m}$ to establish two or more new carbon capture storage clusters by 2030' (Budget 2020 announcement, 11 March 2020). This investment is, of course, welcome, but will not be sufficient to allow the necessary, widespread commercialization of CCS in the UK.

There is an elegiac quality to this Memoir, with fields documented here reflecting the emergence of the UK's petroleum basins, the boom times, the ups and downs of the oil price cycle, and the inevitable decline of UKCS oil and gas production, notwithstanding the industry's ability to discover and commercialize increasingly more challenging accumulations. At the time of writing, the oil price has just collapsed to below $\$ 30 / \mathrm{bbl}$ as a consequence of the Coronavirus pandemic and the cessation of OPEC-Russia collaboration to support the price. Oil prices at this level will likely focus companies on survival rather than on rapidly progressing a pre-commercial technology such as CCS. From the perspective of future employment, opportunity creation and reduction of emissions, we must argue to the public and to politicians that greater action to encourage CCS is needed and our industry needs the opportunity to use all its skills, expertise and dynamism to play a positive role in the energy transition. In the meantime, we should be proud of the role our industry has played for more than 50 years and will continue to play as the energy transition develops. The editors hope that this Memoir can play a small part in that process.

Acknowledgements A Memoir of this scale is the result of the contributions of a remarkably large number of people. The editors are immensely grateful to all of the authors and their companies for support in writing papers. Jonathan Craig in particular was also most helpful at the outset. At the Geological Society's Publishing House, Angharad Hills (now retired), Bethan Phillips and Maggie Simmons have been hugely helpful whilst Jo Armstrong and her team have done sterling work in delivering a fantastic publication. Jen Brzozowska very kindly compiled from various sources the Memoir's Dedication to John Brooks. Lastly, but by no means least, a large cadre of people have reviewed the papers in this volume and the editors are most grateful to all of the reviewers (listed below) for their time and hard work:

Mark Abbot, Juan Alcalde, Stuart Archer, John Argent, Mark Attree, Judith Ayers Morgan, Adam Baldwin, Maurice Bamford, Greg Baniak, Bernard Besly, Richard Blight, Mike Bowman, Hervey Breese, Steve Brown, John Colleran, Susan Daniels, Mike Darke, Hugh Dennis, Paul Doubleday, Joe Cartwright, Steve Corbin, Andrew Crouch, Eddie Dempsey, Martin Durham, Dave Ellis, Nigel Evans, Jo Garland, Steve Garrett, Rod Gilham, Caroline Gill, Fiona Goodfellow, Neil Grant, Alyson Harding, Jim Henderson, Paul Herrington, Richard Hodgkinson, Neil Hodgson, Paul Howlett, Andy Hurst, Mads Huuse, Martin Insley, Alan Irving, Noah Jaffey, Stephanie Kape, Simon Kettle, Wayne Kirk, Henk Kombrink, Adam Law, David Lawton, Dave Lewis, Andy Los, Jeremy Lynch, Gwilym Lynn, James Maynard, Tom McKie, Trevor McMurray, Neil Meadows, Marilyn Merryweather, Keith Milne, Peter Mohr, Darren Moody, Colin More, Andy Mortimer, Jim Munns, Helen Naylor, Hugh Nicholson, David Offer, Tobore Orife, Neil Parkinson, Jon Parry, Colin Percival, Steve Pinnock, Graham Pritchard, Kevin
Purvis, Jo Reader, Jon Redfern, Phil Rose, Pamela Sansom, Mike Scotting, Simone Silcock, Andy Sims, Nick Stronach, Gordon Taylor, Helen Turnell, Bernie Vining, Duncan Wade, Gavin Ward, Kelsey Ward, Debbie Ware, John Wild, Lucy Williams, Edwige Zanella.

Funding This research received no specific grant from any funding agency in the public, commercial, or not-for-profit sectors.

Author contributions GG: conceptualization (lead), writing original draft (lead); JG: writing - review \& editing (supporting); NS: visualization (equal), writing - review \& editing (supporting).

\section{References}

Аввотs, I.L. 1991. United Kingdom Oil and Gas Fields, 25 Years Commemorative Volume. Geological Society, London, Memoirs, 14, https://doi.org/10.1144/GSL.MEM.1991.014.01.01

Allan, N.P. \& Southwood, D.A. 2020. The Perth Field, Blocks 14/ 25a, 15/21c, 15/21e, UK North Sea. In: GofFEy, G. \& GluYAS, J.G. (eds) United Kingdom Oil and Gas Fields: 50th Anniversary Commemorative Volume. Geological Society, London, Memoirs, 52, https://doi.org/10.1144/M52-2019-38

Anston-Race, S.E. \& Ganesh, D. 2020. The Viking Fields, Blocks 49/11d, 49/12a, 49/16a, 49/16c, 49/17a, UK North Sea. In: GofFey, G. \& Gluyas, J.G. (eds) United Kingdom Oil and Gas Fields: 50th Anniversary Commemorative Volume. Geological Society, London, Memoirs, 52, https://doi.org/10.1144/ M52-2018-55

Baldwin, A. 2020. The Wood, Cayley, Godwin and Shaw fields, Blocks 22/17s, 22/18a and 22/22a, UK North Sea. In: Gofrey, G. \& Gluyas, J.G. (eds) United Kingdom Oil and Gas Fields: 50th Anniversary Commemorative Volume. Geological Society, London, Memoirs, 52, https://doi.org/10.1144/ M52-2018-9

Ball, R. \& Gluyas, J. 2020. The Dunlin, Dunlin SW, Osprey and Merlin fields, Blocks $211 / 23$ and $211 / 24$, UK North Sea. In: Gofrey, G. \& Gluyas, J.G. (eds) United Kingdom Oil and Gas Fields: 50th Anniversary Commemorative Volume. Geological Society, London, Memoirs, 52, https://doi.org/10.1144/ M52-2018-30

Baniak, G.M., Sayer, Z., Patterson, H., Gooder, R., Laing, N. \& Love, A. 2020. The Mungo Field, Blocks 22/20a and 23/16a, UK North Sea. In: GofFey, G. \& GLuYAS, J.G. (eds) United Kingdom Oil and Gas Fields: 50th Anniversary Commemorative Volume. Geological Society, London, Memoirs, 52, https://doi. org/10.1144/M52-2018-82

Beckly, A.J., Nash, T., Pollard, R., Bruce, C., Freeman, P. \& Page, G. 2003. The Harding Field, Block 9/23b. In: Gluyas, J. \& Hichens, H. (eds) United Kingdom Oil and Gas Fields, Commemorative Millennium Volume. Geological Society, London, Memoirs, 20, 283-290.

Belaidi, A., Bonter, D.A., Slightam, C. \& Trice, R. 2018. The Lancaster Field: progress in opening the UK's fractured basement play. In: Bowman, M. \& Levell, B. (eds) Petroleum Geology of NW Europe: 50 Years of Learning - Proceedings of the 8th Petroleum Geology Conference. Geological Society, London, 385-398, https://doi.org/10.1144/PGC8.20

Bentham, M. 2006. An assessment of carbon sequestration potential in the UK - Southern North Sea case study. Tyndall Centre Working Paper, 85, https://tyndall.ac.uk/reports/ working-papers

Botman, R.J. \& van LiER, J. 2020. The Sean fields, Block 49/25a, UK North Sea. In: Goffey, G. \& Gluyas, J.G. (eds) United Kingdom Oil and Gas Fields: 50th Anniversary Commemorative Volume. Geological Society, London, Memoirs, 52, https://doi.org/10. 1144/M52-2019-11

Brown, G., Platt, N.H. \& McGrandle, A. 1994. The geophysical expression of Tertiary dykes in the southern North Sea. First Break, 12, 137-146. 
Brown, S.A., Wood, P.H., Bamford, M.L.F. \& Gluyas, J.G. 2020. The Pilot, Elke, Blakeney, Narwhal, Harbour and Feugh fields, Blocks $21 / 27,21 / 28,28 / 2$ and $28 / 3$, UK North Sea. In: Goffey, G. \& Gluyas, J.G. (eds) United Kingdom Oil and Gas Fields: 50th Anniversary Commemorative Volume. Geological Society, London, Memoirs, 52, https://doi.org/10.1144/ M52-2017-25

Bunce, J. 2020a. The Douglas Field, Block 110/13b, UK East Irish Sea. In: Goffey, G. \& GLuYAs, J.G. (eds) United Kingdom Oil and Gas Fields: 50th Anniversary Commemorative Volume. Geological Society, London, Memoirs, 52, https://doi.org/10. 1144/M52-2019-25

Bunce, J. 2020b. The Lennox Field, Blocks 110/14c and 110/15a, UK East Irish Sea. In: Goffey, G. \& Gluyas, J.G. (eds) United Kingdom Oil and Gas Fields: 50th Anniversary Commemorative Volume. Geological Society, London, Memoirs, 52, https://doi. org/10.1144/M52-2019-13

Camm, M., Armstrong, L.E. \& Patel, A. 2020. The Britannia Field, Blocks 15/29, 15/30, 16/26 and 16/27, UK North Sea. In: Gofrey, G. \& Gluyas, J.G. (eds) United Kingdom Oil and Gas Fields: 50th Anniversary Commemorative Volume. Geological Society, London, Memoirs, 52, https://doi.org/10.1144/ M52-2018-54

CANDY, G. 1983. Petroleum exploration Onshore UK. In: BRooKs, J. (ed.) Petroleum Geochemistry and Exploration of Europe. Geological Society, London, Special Publications, 12, 67-68, https://doi.org/10.1144/GSL.SP.1983.012.01.08

Carruth, A.G. 2003. The Foinaven Field, Blocks 204/19, 204/24a, UK North Sea. In: Gluyas, J.G. \& Hichens, H. (eds) United Kingdom Oil and Gas Fields, Commemorative Millenium Volume. Geological Society, London, Memoirs, 20, 121-132.

Christiansen, S.H. \& WiLson, P.M. 1997. Challenges in the Brent Field: Implementation of Depressurisation. Offshore Europe, 9-12 September, Aberdeen, UK, https://doi.org/10.2118/38469-MS

Clark, J., Matthews, P., Parry, C., Rowlands, M. \& Tessier, A. 2020a. The Laggan and Tormore fields, Blocks 206/1 and 205/5, UK Atlantic Margin. In: Gofrey, G. \& Gluyas, J.G. (eds) United Kingdom Oil and Gas Fields: 50th Anniversary Commemorative Volume. Geological Society, London, Memoirs, 52, https://doi.org/10.1144/M52-2018-25

Clark, J., Parry, C., Rowlands, M., Tessier, A. \& Mazzuchelli, D. 2020b. The Glenlivet Field, Block 214/30a, UK Atlantic Margin. In: Gofrey, G. \& Gluyas, J.G. (eds) United Kingdom Oil and Gas Fields: 50th Anniversary Commemorative Volume. Geological Society, London, Memoirs, 52, https://doi.org/10. 1144/M52-2018-24

Clark, J., Mazzuchelli, D., Rowlands, M., Jebara, N. \& Parry, C. 2020c. The Edradour Field, Block 206/4a, UK Atlantic Margin. In: Gofrey, G. \& Gluyas, J.G. (eds) United Kingdom Oil and Gas Fields: 50th Anniversary Commemorative Volume. Geological Society, London, Memoirs, 52, https://doi.org/10.1144/ M52-2018-23

Couch, A.G., Eatwell, S. \& Daini, O. 2020. The Huntington Field, 22/14a, UK North Sea. In: Goffey, G. \& GluyAs, J.G. (eds) United Kingdom Oil and Gas Fields: 50th Anniversary Commemorative Volume. Geological Society, London, Memoirs, 52, https://doi.org/10.1144/M52-2018-33

Craig, J., Gerali, F., MacAulay, F. \& Sorkhabi, R. 2018. The history of the European oil and gas industry (1600s-2000s). In Craig, J., Gerali, F., MacAulay, F. \& Sorkhabi, R. (eds) 2018. History of the European Oil and Gas Industry. Geological Society, London, Special Publications, 465, 1-24, https://doi. org $/ 10.1144 /$ SP465.23

Dawson, C. 1898. On the discovery of Natural Gas in East Sussex. Quarterly Journal of the Geological Society, 54, 564-571, https://doi.org/10.1144/GSL.JGS.1898.054.01-04.38

DECC 2013. The Hydrocarbon Prospectivity of Britain's Onshore Basins. https://www.ogauthority.co.uk/media/1695/uk_on shore_2013.pdf [accessed 21 November 2019]

Dredge, I. \& Marsden, G. 2020. The Cygnus Field, Block 44/11a and 44/12A, UK North Sea. In: Goffey, G. \& GluYAs, J.G. (eds) United Kingdom Oil and Gas Fields: 50th Anniversary
Commemorative Volume. Geological Society, London, Memoirs, 52, https://doi.org/10.1144/M52-2018-69

Drummond, A., Fishlock, T., NAylor, P. \& Rothkopf, B. 2001. An Evaluation of Post-Waterflood Depressurisation of the South Brae Field, North Sea. SPE Annual Technical Conference and Exhibition, 30 Sept-3 Oct, New Orleans, LA, https://doi.org/ 10.2118/71487-MS

Duncan, L.J., Dennehy, C.J., Ablard, P.M. \& Wallis, D.W. 2020. The Rosebank Field, Blocks 213/27a, 213/26b, 205/1a and 205/2a, UK Atlantic Margin. In: Goffey, G. \& GluyAs, J.G. (eds) United Kingdom Oil and Gas Fields: 50th Anniversary Commemorative Volume. Geological Society, London, Memoirs, 52, https://doi.org/10.1144/M52-2018-42

Falcon, N.L. \& Kent, P.E. 1960. Geological Results of Petroleum Exploration in Britain 1945-1957. Geological Society, London, Memoirs, 2, https://doi.org/10.1144/GSL.MEM.1960.002.01.01

Freeman, C.J.F., Garrard, R.J. \& Farwana, A. 2020. Starling, Scoter and Merganser fields, Blocks 22/30a \& 29/3a, UK North Sea. In: GofFey, G. \& GuuYAs, J.G. (eds) United Kingdom Oil and Gas Fields: 50th Anniversary Commemorative Volume. Geological Society, London, Memoirs, 52, https://doi.org/10. 1144/M52-2018-63

Frenz, T., Besly, B. \& Marriott, J. 2020. The Pelican Field, Block 211/26a, UK North Sea. In: GofFey, G. \& GluYAs, J.G. (eds) United Kingdom Oil and Gas Fields: 50th Anniversary Commemorative Volume. Geological Society, London, Memoirs, 52, https://doi.org/10.1144/M52-2019-46

GEBCO Bathymetric Compilation Group 2019. GEBCO 2019 Grid - a continuous terrain model of the global oceans and land. British Oceanographic Data Centre, National Oceanography Centre, NERC, UK, https://doi.org/10.5285/836f016a33be-6ddc-e053-6c86abc0788e

Gibson, M., Riley, D., Kenyon-Roberts, S., Opata, J., Beck, A., NguYen, C. \& Martin, T. 2020. The Catcher, Varadero and Burgman fields, Block 28/9a, UK North Sea. In: GofFEY, G. \& Gluyas, J.G. (eds) United Kingdom Oil and Gas Fields: 50th Anniversary Commemorative Volume. Geological Society, London, Memoirs, 52, https://doi.org/10.1144/ M52-2019-24

Gluyas, J.G. \& Arkley, P. 2020. The Innes Field, Block 30/24, UK North Sea. In: Goffey, G. \& GluYAs, J.G. (eds) United Kingdom Oil and Gas Fields: 50th Anniversary Commemorative Volume. Geological Society, London, Memoirs, 52, https://doi.org/10. 1144/M52-2017-17

Gluyas, J. \& Bagudu, U. 2020. The Endurance $\mathrm{CO}_{2}$ storage site, Blocks $42 / 25$ and $43 / 21$, UK North Sea. In: Goffey, G. \& GluYAs, J.G. (eds) United Kingdom Oil and Gas Fields: 50th Anniversary Commemorative Volume. Geological Society, London, Memoirs, 52, https://doi.org/10.1144/M52-2019-47

Gluyas, J.G. \& Hichens, H.M. 2003. United Kingdom Oil and Gas Fields Commemorative Millennium Volume. Geological Society, London, Memoirs, 20, https://doi.org/10.1144/GSL. MEM.2003.020.01.02

Gluyas, J., De-Paola, N. et Al. 2020a. The Humbly Grove, Herriard and Hester's Copse fields, UK Onshore. In: Goffey, G. \& Gluyas, J.G. (eds) United Kingdom Oil and Gas Fields: 50th Anniversary Commemorative Volume. Geological Society, London, Memoirs, 52, https://doi.org/10.1144/M52-2018-78

Gluyas, J., Turnell, H. ET al. 2020b. The Hutton, NW Hutton, Q-West and Darwin fields, Blocks 211/27 and 211/28, UK North Sea. In: GofFEy, G. \& GLuYAs, J.G. (eds) United Kingdom Oil and Gas Fields: 50th Anniversary Commemorative Volume. Geological Society, London, Memoirs, 52, https://doi.org/10. 1144/M52-2018-67

Gluyas, J.G., SŁowakiewicz, M., Tucker, M.E. \& Gutteridge, P. $2020 c$. The Morag Field, Block 16/29a, UK North Sea. In: Goffey, G. \& Gluyas, J.G. (eds) United Kingdom Oil and Gas Fields: 50th Anniversary Commemorative Volume. Geological Society, London, Memoirs, 52, https://doi.org/10.1144/ M52-2018-90

Goffey, G. 2020. The Birgitta Field, Block 22/19a, UK North Sea. In: Goffey, G. \& GluYas, J.G. (eds) United Kingdom Oil and 
Downloaded from http://mem.lyellcollection.org/ by guest on October 29, 2021

Gas Fields: 50th Anniversary Commemorative Volume. Geological Society, London, Memoirs, 52, https://doi.org/10.1144/ M52-2018-18

Goffey, G., LunN, S. \& Seedhouse, J. 2020. The Brechin Field, Block 22/23a, UK North Sea. In: Goffey, G. \& Gluyas, J.G. (eds) United Kingdom Oil and Gas Fields: 50th Anniversary Commemorative Volume. Geological Society, London, Memoirs, 52, https://doi.org/10.1144/M52-2018-77

Hagen, F., GluYas, J.G. \& Goffey, G. 2020. The Acorn and Beechnut fields, Blocks 29/8a(S), 29/8b and 29/9a(S) and 29/9b, UK North Sea. In: Goffey, G. \& Gluyas, J.G. (eds) United Kingdom Oil and Gas Fields: 50th Anniversary Commemorative Volume. Geological Society, London, Memoirs, 52, https://doi.org/10. 1144/M52-2018-31

Hale, M., Laird, R., Gavnholt, J. \& van Bergen, P.F. 2020. The Pierce Field, Blocks 23/22a and 23/27, UK North Sea. In: GoFFEY, G. \& Gluyas, J.G. (eds) United Kingdom Oil and Gas Fields: 50th Anniversary Commemorative Volume. Geological Society, London, Memoirs, 52, https://doi.org/10.1144/M522018-22

Hampson, M., Martin, H., Craddock, L., Wood, T. \& Rylands, E. 2020. The Elswick Field, Bowland Basin, UK Onshore. In: GoFFey, G. \& Gluyas, J.G. (eds) United Kingdom Oil and Gas Fields: 50th Anniversary Commemorative Volume. Geological Society, London, Memoirs, 52, https://doi.org/10.1144/ M52-2017-29

Harrison, D., Haarhoff, M., Heath-Clarke, M., Hodgson, W., Hughes, F., Ware, D. \& Mortimer, A. 2020. The Vale of Pickering gas fields, Kirby Misperton, Malton, Marishes and Pickering, North Yorkshire, UK Onshore. In: GoFFEY, G. \& Gluyas, J.G. (eds) United Kingdom Oil and Gas Fields: 50th Anniversary Commemorative Volume. Geological Society, London, Memoirs, 52, https://doi.org/10.1144/M52-2017-33

Heath, R. \& Robertson, K. 2020. The Burghley Field, Block 16/22, UK North Sea. In: Goffey, G. \& Gluyas, J.G. (eds) United Kingdom Oil and Gas Fields: 50th Anniversary Commemorative Volume. Geological Society, London, Memoirs, 52, https://doi. org/10.1144/M52-2018-13

Hodgins, B., Moy, D.J. \& Carnicero, P.A. 2020. The Captain Field, Block 13/22a, UK North Sea. In: Goffey, G. \& GluYAs, J.G. (eds) United Kingdom Oil and Gas Fields: 50th Anniversary Commemorative Volume. Geological Society, London, Memoirs, 52, https://doi.org/10.1144/M52-2018-92

Hook, J.A. 2020a. The Hewett Field, Blocks 48/28a, 48/29a, 48/30a, 52/4a and 52/5a, UK North Sea. In: Goffey, G. \& Gluyas, J.G. (eds) United Kingdom Oil and Gas Fields: 50th Anniversary Commemorative Volume. Geological Society, London, Memoirs, 52, https://doi.org/10.1144/M522019-40

Hоок, J.A. 2020b. The Hewett Field satellites: Big Dotty, Little Dotty, Deborah, Della, Dawn and Delilah, Blocks 48/29a, 48/ 30a, UK North Sea. In: Goffey, G. \& Gluyas, J.G. (eds) United Kingdom Oil and Gas Fields: 50th Anniversary Commemorative Volume. Geological Society, London, Memoirs, 52, https://doi. org/10.1144/M52-2019-41

Horsfall, P. 2020. The Solan Field, Block 205/26a, UK Atlantic Margin. In: Goffey, G. \& GluYAS, J.G. (eds) United Kingdom Oil and Gas Fields: 50th Anniversary Commemorative Volume. Geological Society, London, Memoirs, 52, https://doi.org/10. 1144/M52-2019-4

Huis in 't Veld, R., Schrijver, B. \& Salzwedel, A. 2020. The Wingate Field, Blocks 44/23b, 44/24b and 44/19f, UK North Sea. In: Goffey, G. \& Gluyas, J.G. (eds) United Kingdom Oil and Gas Fields: 50th Anniversary Commemorative Volume. Geological Society, London, Memoirs, 52, https://doi.org/10.1144/ M52-2018-75

Ings, R.J., Davids, D., Shotton, P. \& Agnew, C. 2020. The Donan, Lochranza and Balloch fields, Blocks 15/20a and 15/20b, UK North Sea. In: Goffey, G. \& Gluyas, J.G. (eds) United Kingdom Oil and Gas Fields: 50th Anniversary Commemorative Volume. Geological Society, London, Memoirs, 52, https://doi.org/10. 1144/M52-2019-32
Irving, A.D., Raphael, K.F., Rennison, P.M., Lewis, R., CruickSHANK, C.D. \& Rengifo, R.A. 2020. The Elgin, Franklin, Glenelg and West Franklin fields, Blocks 22/30b, 22/30c, 29/4d, 29/5b and 29/5c, UK North Sea. In: GofFEy, G. \& Gluyas, J.G. (eds) United Kingdom Oil and Gas Fields: 50th Anniversary Commemorative Volume. Geological Society, London, Memoirs, 52, https://doi.org/10.1144/M52-2018-47

Jena, S. \& Olowoleru, D. 2020. The Lomond Field, Block 23/21, UK North Sea. In: Goffey, G. \& GLuYAS, J.G. (eds) United Kingdom Oil and Gas Fields: 50th Anniversary Commemorative Volume. Geological Society, London, Memoirs, 52, https://doi. org/10.1144/M52-2019-37

Johnson, M. \& Evans, G.J. 2020. The Crosby Warren Field, Block DL001, UK Onshore. In: Goffey, G. \& Gluyas, J.G. (eds) United Kingdom Oil and Gas Fields: 50th Anniversary Commemorative Volume. Geological Society, London, Memoirs, 52, https://doi.org/10.1144/M52-2018-29

Karlo, J., van Buchem, F.S.P., Moen, J. \& Milroy, K. 2014. Triassic-age salt tectonics of the Central North Sea. Interpretation, 2, 19-28.

KING, L. 2020. The UK North Sea: a history of oil and gas. In: GoFFEY, G. \& Gluyas, J.G. (eds) United Kingdom Oil and Gas Fields: 50th Anniversary Commemorative Volume. Geological Society, London, Memoirs, 52, https://doi.org/10.1144/M522019-22

Lawrence, H.M., Armstrong, L.E., Ashton, K., Jones, A.D. \& Mearns, I.E. 2020. The Jasmine Field, Blocks 30/06, 30/07a, UK North Sea. In: GofFey, G. \& GluYAs, J.G. (eds) United Kingdom Oil and Gas Fields: 50th Anniversary Commemorative Volume. Geological Society, London, Memoirs, 52, https://doi. org/10.1144/M52-2018-53

LiebnitZ, S. 2020. The Howe and Bardolino fields, Blocks 22/12a and 22/13a, UK North Sea. In: Goffey, G. \& GluyAs, J.G. (eds) United Kingdom Oil and Gas Fields: 50th Anniversary Commemorative Volume. Geological Society, London, Memoirs, 52, https://doi.org/10.1144/M52-2019-23

LeEs, G.M. \& TAIT, A.H. 1945. The geological results of the search for oil field in Great Britain. Quarterly Journal of the Geological Society, 101, 255-317, https://doi.org/10.1144/GSL.JGS. 1945.101.01-04.12

Miles, A., Allen, M., Fairweather, L., Hilton, J., Sloan, H. \& Zapico-Palmero, P. 2020. The Tolmount Field, Block 42/28d, UK North Sea. In: Gofrey, G. \& Gluyas, J.G. (eds) United Kingdom Oil and Gas Fields: 50th Anniversary Commemorative Volume. Geological Society, London, Memoirs, 52, https://doi. org/10.1144/M52-2018-16

Milner, P., Whailing, P.J., Ridings, J. \& Gill, J. 2020. The Kilmar Field, Block 43/22a, UK North Sea. In: GofFey, G. \& GluyAS, J.G. (eds) United Kingdom Oil and Gas Fields: 50th Anniversary Commemorative Volume. Geological Society, London, Memoirs, 52, https://doi.org/10.1144/M52-2018-50

Moore, I., Archer, J. \& Peavot, D. 2020. The Alba Field, Block 16/ 26a, UK North Sea. In: GoFrey, G. \& GluYAS, J.G. (eds) United Kingdom Oil and Gas Fields: 50th Anniversary Commemorative Volume. Geological Society, London, Memoirs, 52, https://doi. org/10.1144/M52-2018-46

Moscariello, A. \& Goffey, G. 2020. The Ketch, Schooner and Topaz fields, Blocks 44/26, 44/28, 49/1a and 49/2a, UK North Sea. In: Goffey, G. \& GluYAS, J.G. (eds) United Kingdom Oil and Gas Fields: 50th Anniversary Commemorative Volume. Geological Society, London, Memoirs, 52, https://doi.org/10.1144/ M52-2019-45

Nwachukwu, C.M., Barnett, Z. \& Gluyas, J.G. 2020. The Breagh Field, Blocks 42/12a, 42/13a and 42/8a, UK North Sea. In: Goffey, G. \& Gluyas, J.G. (eds) United Kingdom Oil and Gas Fields: 50th Anniversary Commemorative Volume. Geological Society, London, Memoirs, 52, https://doi.org/10.1144/ M52-2019-15

Nygaard, J., Caulfield, M., Gooder, R. \& Chedburn, D. 2020. The Culzean Field, Block 22/25a, UK North Sea. In: GofFeY, G. \& Gluyas, J.G. (eds) United Kingdom Oil and Gas Fields: 50th Anniversary Commemorative Volume. Geological 
Society, London, Memoirs, 52, https://doi.org/10.1144/M522019-26

OfFer, D.J. 2020. The Juliet Field, Block 47/14b, UK North Sea. In: Goffey, G. \& Gluyas, J.G. (eds) United Kingdom Oil and Gas Fields: 50th Anniversary Commemorative Volume. Geological Society, London, Memoirs, 52, https://doi.org/10.1144/ M52-2017-14

OGA 2019. Full list of Offshore Field Consents. https://www.ogau thority.co.uk/data-centre/data-downloads-and-publications/fielddata/ [accessed 19 November 2019].

OGUK 2018. Energy Transition Outlook 2018, Oil and Gas UK. https://oilandgasuk.co.uk/wp-content/uploads/2019/03/OGUKEnergy-Transition-Outlook-2018.pdf [accessed 22 November 2019].

Parkes, L., Wood, P. \& Macdonald, C. 2020. The Kraken and Kraken North fields, Block 9/2b, UK North Sea. In: GoFFEY, G. \& Gluyas, J.G. (eds) United Kingdom Oil and Gas Fields: 50th Anniversary Commemorative Volume. Geological Society, London, Memoirs, 52, https://doi.org/10.1144/M522018-64

Patroni Zavala, J.A., Taylor, M., Tiltman, C.J. \& Sime, N.G. 2020. The Rhyl Field, Block $113 / 27$ b, UK East Irish Sea. In: Goffey, G. \& Gluyas, J.G. (eds) United Kingdom Oil and Gas Fields: 50th Anniversary Commemorative Volume. Geological Society, London, Memoirs, 52, https://doi.org/10. 1144/M52-2018-84

Pelletier, F. \& Gunn, C. 2020. The Gryphon, Maclure, Tullich and Ballindalloch fields, Blocks 9/18b, 9/18c, 9/19a, 9/23d and 9/24e, UK North Sea. In: Goffey, G. \& Gluyas, J.G. (eds) United Kingdom Oil and Gas Fields: 50th Anniversary Commemorative Volume. Geological Society, London, Memoirs, 52, https://doi.org/10.1144/M52-2018-91

Phipps, R.M. \& Tiltman, C.J. 2020. The Babbage Field, Block 48/2a, UK North Sea. In: Goffey, G. \& Gluyas, J.G. (eds) United Kingdom Oil and Gas Fields: 50th Anniversary Commemorative Volume. Geological Society, London, Memoirs, 52, https://doi. org/10.1144/M52-2019-1

Pinnock, S.J. \& Dutton, D.M. 2020. The Golden Eagle, Peregrine and Solitaire fields, Blocks 14/26a and 20/01, UK North Sea. In: Gofrey, G. \& Gluyas, J.G. (eds) United Kingdom Oil and Gas Fields: 50th Anniversary Commemorative Volume. Geological Society, London, Memoirs, 52, https://doi.org/10.1144/ M52-2017-39

Rieu, R. \& Porter, R.J. 2020. The Carrack Field, Blocks 49/14b, 49/15a and 49/15b, UK North Sea. In: GoFFEy, G. \& GLUYAS, J.G. (eds) United Kingdom Oil and Gas Fields: 50th Anniversary Commemorative Volume. Geological Society, London, Memoirs, 52, https://doi.org/10.1144/M52-2020-9

Robertson, A.G., BaLl, M. ET AL. 2020. The Clair Field, Blocks 206/ 7a, 206/8, 206/9a, 206/12a and 206/13a, UK Atlantic Margin. In: Goffey, G. \& GluYAs, J.G. (eds) United Kingdom Oil and Gas Fields: 50th Anniversary Commemorative Volume. Geological Society, London, Memoirs, 52, https://doi.org/10.1144/ M52-2018-76

RoberTSON, I. 2020. The Erskine Field, Block 23/26b, UK North Sea. In: Goffey, G. \& Gluyas, J.G. (eds) United Kingdom Oil and Gas Fields: 50th Anniversary Commemorative Volume. Geological Society, London, Memoirs, 52, https://doi.org/10. 1144/M52-2018-72

Robertson, K., Heath, R. \& MacDonald, R. 2020a. The Blane Field, Block 30/3a, UK North Sea. In: Goffey, G. \& GluYAs, J.G. (eds) United Kingdom Oil and Gas Fields: 50th Anniversary Commemorative Volume. Geological Society, London, Memoirs, 52, https://doi.org/10.1144/M52-2018-15

Robertson, K., Heath, R. \& McKenzie, A. 2020b. The Enoch Field, Block 16/13a, UK North Sea. In: GofFey, G. \& GLUYAS, J.G. (eds) United Kingdom Oil and Gas Fields: 50th Anniversary Commemorative Volume. Geological Society, London, Memoirs, 52, https://doi.org/10.1144/M52-2018-14

Rose, P.T.S., Byerley, G.W. et al. 2020. The Forties Field, Blocks $21 / 10$ and 22/6a, UK North Sea. In: GofFey, G. \& GluYAS, J.G. (eds) United Kingdom Oil and Gas Fields: 50th
Anniversary Commemorative Volume. Geological Society, London, Memoirs, 52, https://doi.org/10.1144/M52-2017-41

Rouillard, P., Bagley, G., Moseley, D., Myers, K. \& Harding, A. 2020. UKCS exploration 50 years and counting. In: GoFFEY, G. \& Gluyas, J.G. (eds) United Kingdom Oil and Gas Fields: 50th Anniversary Commemorative Volume. Geological Society, London, Memoirs, 52, https://doi.org/10.1144/M522018-66

SAtur, N., BANG, A., SkJRPe, I. \& Muehlboceck, S. 2017. Evolution of the interpretation of the Volund Field (conference abstract). Subsurface Sand Remobilization and Injection: Implications for Oil and Gas Exploration and Development, 22-23 March 2017, Geological Society, London, https://www.geolsoc.org. $\mathrm{uk} / \sim$ media/shared/documents/groups/specialist/petroleum/ 2017/Sand\%20Injectites\%20Abstract\%20Book\%2022-23\%20 March\%202017.pdf?la=en

SAundRy, E. \& Colmenares, J. 2020. The Blake Field, Blocks 13/24a and 13/29b, UK North Sea. In: Goffey, G. \& GluYAs, J.G. (eds) United Kingdom Oil and Gas Fields: 50th Anniversary Commemorative Volume. Geological Society, London, Memoirs, 52, https://doi.org/10.1144/M52-2018-10

SAyer, Z., Edet, J., Gooder, R. \& Love, A. 2020. The Machar Field, Block 23/26a, UK North Sea. In: Goffey, G. \& Gluyas, J.G. (eds) United Kingdom Oil and Gas Fields: 50th Anniversary Commemorative Volume. Geological Society, London, Memoirs, 52, https://doi.org/10.1144/M52-2018-45

Silcock, S.Y., Baptie, R.J., Iheobi, A., Frost, S., Simms, A. \& BretTLE, M. 2020. The Mariner Field, Block 9/11a, UK North Sea. In: Goffey, G. \& Gluyas, J.G. (eds) United Kingdom Oil and Gas Fields: 50th Anniversary Commemorative Volume. Geological Society, London, Memoirs, 52, https://doi.org/10.1144/ M52-2017-44

Smit, W. 2020. Chiswick and Kew fields, Blocks 49/4a, 49/4b, 49/ $4 \mathrm{c}, 49 / 5 \mathrm{a}$ and $49 / 5 \mathrm{~b}$, UK North Sea. In: GofFey, G. \& GLuYAS, J.G. (eds) United Kingdom Oil and Gas Fields: 50th Anniversary Commemorative Volume. Geological Society, London, Memoirs, 52, https://doi.org/10.1144/M52-2018-48

Stephens, I.N., Small, S. \& Wood, P.H. 2020. The Maria Field, Block 16/29a, UK North Sea. In: Gofrey, G. \& Gluyas, J.G. (eds) United Kingdom Oil and Gas Fields: 50th Anniversary Commemorative Volume. Geological Society, London, Memoirs, 52, https://doi.org/10.1144/M52-2019-6

Stewart, N. \& Marshall, J.D. 2020. The Goldeneye Field, Blocks 14/29a and 20/4b, UK North Sea. In: GofFey, G. \& Gluyas, J.G. (eds) United Kingdom Oil and Gas Fields: 50th Anniversary Commemorative Volume. Geological Society, London, Memoirs, 52, https://doi.org/10.1144/M522018-32

Storey, M.W. \& NASh, D.F. 1993. The Eakring Dukeswood oil field: an unconventional technique to describe a field's geology. In: PARKer, J.R. (ed.) Petroleum Geology of Northwest Europe: Proceedings of the 4th Conference. Geological Society, London, 1527-1537, https://doi.org/10.1144/0041527

Sturt, B. 1993. Low Finance in the High Weald. Paper to London and Southern Gas Association, June 1993. East Sussex Records Office, AMS 6920.

TANG, L., GluYAS, J., JoNeS, S. \& BesLy, B. 2020. The Alma (formerly Argyll/Ardmore) Field, Blocks 30/24 and 30/25a, UK North Sea. In: GofFey, G. \& Gluyas, J.G. (eds) United Kingdom Oil and Gas Fields: 50th Anniversary Commemorative Volume. Geological Society, London, Memoirs, 52, https://doi.org/10. 1144/M52-2017-34

TAYLOR, B.J. \& JONES, D.W. 2020. The Shearwater Field, Blocks 22/ $30 \mathrm{~b}$ and 22/30e, UK North Sea. In: GofFey, G. \& Gluyas, J.G. (eds) United Kingdom Oil and Gas Fields: 50th Anniversary Commemorative Volume. Geological Society, London, Memoirs, 52, https://doi.org/10.1144/M52-2019-28

Taylor, E.E., Webb, N.J., Stevenson, C.J., Henderson, J.R., Kovac, A., Millington, J.J. \& Rhodes, J.A. 2020. The Buzzard Field, Blocks 19/5a, 19/10a, 20/1 and 20/6a, UK North Sea. In: GoFFEy, G. \& Gluyas, J.G. (eds) United Kingdom Oil and Gas Fields: 50th Anniversary Commemorative Volume. Geological 
Downloaded from http://mem.lyellcollection.org/ by guest on October 29, 2021

Society, London, Memoirs, 52, https://doi.org/10.1144/M522019-17

Tegerdine, G. 2020a. The Renee Field, Block 15/27a, UK North Sea. In: Goffey, G. \& Gluyas, J.G. (eds) United Kingdom Oil and Gas Fields: 50th Anniversary Commemorative Volume. Geological Society, London, Memoirs, 52, https://doi.org/10. 1144/M52-2017-27

Tegerdine, G. 2020b. The Rubie Field, Block 15/28b, UK North Sea. In: Goffey, G. \& Gluyas, J.G. (eds) United Kingdom Oil and Gas Fields: 50th Anniversary Commemorative Volume. Geological Society, London, Memoirs, 52, https://doi.org/10.1144/ M52-2018-3

Thorpe, D., Porter, M., McKie, T. \& Ritchie, L.J. 2020. The Penguins Cluster, Blocks 211/13a and 211/14, UK North Sea. In: Gofrey, G. \& GluYAs, J.G. (eds) United Kingdom Oil and Gas Fields: 50th Anniversary Commemorative Volume. Geological Society, London, Memoirs, 52, https://doi.org/10.1144/ M52-2018-71

VAn OjiK, K., Silvius, A., Kremer, Y. \& Shipton, Z.K. 2019. Fault seal behaviour in Permian Rotliegend reservoir sequences: case studies from the Dutch Southern North Sea. In: Ogilvie, S.R., Dee, S.J., Wilson, R.W. \& Bailey, W.R. (eds) Integrated Fault Seal Analysis. Geological Society, London, Special Publications, 496, https://doi.org/10.1144/SP496-2018-189

van Oorschot, R., Smit, W. \& Glebova, A. 2020a. The Grove Field, Blocks 49/10a, 49/9c, 49/10c, UK North Sea. In: Goffey, G. \& Gluyas, J.G. (eds) United Kingdom Oil and Gas Fields: 50th Anniversary Commemorative Volume. Geological Society, London, Memoirs, 52, https://doi.org/10.1144/ M52-2018-79

van Oorschot, R., Fletcher, A., Basford, H. \& Stuart, A. $2020 b$. The Chestnut Field, Block 22/2a, UK North Sea. In: GoFFEY, G. \& Gluyas, J.G. (eds) United Kingdom Oil and Gas Fields: 50th Anniversary Commemorative Volume. Geological Society, London, Memoirs, 52, https://doi.org/10.1144/ M52-2018-81

Verlinden, V.W.J. \& Basford, H. 2020. The Ensign Field, Blocks 48/14a, 48/15a and 48/15b, UK North Sea. In: GofFEY, G. \& Gluyas, J.G. (eds) United Kingdom Oil and Gas Fields: 50th Anniversary Commemorative Volume. Geological
Society, London, Memoirs, 52, https://doi.org/10.1144/M522018-87

WARD, K.L. \& Folorunso, F. 2020. The Corringham, GainsboroughBeckingham, Glentworth, Nettleham, Stainton and Welton fields, UK Onshore. In: Goffey, G. \& GLuYAs, J.G. (eds) United Kingdom Oil and Gas Fields: 50th Anniversary Commemorative Volume. Geological Society, London, Memoirs, 52, https://doi. org/10.1144/M52-2018-21

Ward, M.V., Primmer, T., Laws, E., Macgregor, K., Harpley, T., Ronald, A. \& ScotT, J. 2020. The Schiehallion and Loyal fields, Blocks 204/20, 204/25a, 204/25b, 205/16, and 205/21b, UK Atlantic Margin. In: Gofrey, G. \& GluYas, J.G. (eds) United Kingdom Oil and Gas Fields: 50th Anniversary Commemorative Volume. Geological Society, London, Memoirs, 52, https://doi. org/10.1144/M52-2019-27

Wasielka, N., Gluyas, J.G., Breese, H. \& Symonds, R. 2020. The Cavendish Field, Block 43/19, UK North Sea. In: GoFFEY, G. \& Gluyas, J.G. (eds) United Kingdom Oil and Gas Fields: 50th Anniversary Commemorative Volume. Geological Society, London, Memoirs, 52, https://doi.org/10.1144/M52-2019-10

WhALEY, J. 2005. North Sea oil and gas exploration: courageous risk takers needed. (eds) GeoExpro, 2(2), https://www.geoexpro. com/articles/2005/03/north-sea-oil-and-gas-exploration-cou rageous-risk-takers-needed [accessed 6 April 2020].

Wright, S., Bramald, J., Brett, D., Dingwall, S., Horsburgh, J. \& Ritchie, A. 2020. The Stella Field, Block 30/6a, UK North Sea. In: Goffey, G. \& Gluyas, J.G. (eds) United Kingdom Oil and Gas Fields: 50th Anniversary Commemorative Volume. Geological Society, London, Memoirs, 52, https://doi.org/10. 1144/M52-2018-8

Wynn, T. \& Saundry, E. 2020. The Buchan Field, Blocks 20/5a and 21/1a, UK North Sea. In: Goffey, G. \& Gluyas, J.G. (eds) United Kingdom Oil and Gas Fields: 50th Anniversary Commemorative Volume. Geological Society, London, Memoirs, 52, https://doi.org/10.1144/M52-2018-11

Young, S. 2009. Oil and gas field names in the central and northern sectors of the North Sea: their provenance, cultural influence, longevity and onshore migration. Nomina, 32, 75-112, http://www.snsbi.org.uk/Nomina_articles/Nomina_32_ Young.pdf 